\title{
Sources and fate of nitrate in groundwater at agricultural operations overlying glacial sediments
}

\author{
Sarah A. Bourke ${ }^{1,2}$, Mike Iwanyshyn ${ }^{3}$, Jacqueline Kohn ${ }^{4}$, and M. Jim Hendry ${ }^{1}$ \\ ${ }^{1}$ Department of Geological Sciences, University of Saskatchewan, Saskatchewan, SK, S7N 5C9, Canada \\ ${ }^{2}$ School of Earth Sciences, University of Western Australia, Crawley, WA, 6009, Australia \\ ${ }^{3}$ Natural Resources Conservation Board, Calgary, AB, T2P 0R4, Canada \\ ${ }^{4}$ Alberta Agriculture and Forestry, Irrigation and Farm Water Branch, Edmonton, AB, T6H 5T6, Canada
}

Correspondence: Sarah A. Bourke (sarah.bourke@uwa.edu.au)

Received: 24 January 2018 - Discussion started: 13 February 2018

Revised: 26 December 2018 - Accepted: 21 January 2019 - Published: 11 March 2019

\begin{abstract}
Leaching of nitrate $\left(\mathrm{NO}_{3}^{-}\right)$from animal waste or fertilisers at agricultural operations can result in $\mathrm{NO}_{3}^{-}$contamination of groundwater, lakes, and streams. Understanding the sources and fate of nitrate in groundwater systems in glacial sediments, which underlie many agricultural operations, is critical for managing impacts of human food production on the environment. Elevated $\mathrm{NO}_{3}^{-}$concentrations in groundwater can be naturally attenuated through mixing or denitrification. Here we use isotopic enrichment of the stable isotope values of $\mathrm{NO}_{3}^{-}$to quantify the amount of denitrification in groundwater at two confined feeding operations overlying glacial sediments in Alberta, Canada. Uncertainty in $\delta^{15} \mathrm{~N}_{\mathrm{NO}_{3}}$ and $\delta^{18} \mathrm{O}_{\mathrm{NO}_{3}}$ values of the $\mathrm{NO}_{3}^{-}$source and denitrification enrichment factors are accounted for using a Monte Carlo approach. When denitrification could be quantified, we used these values to constrain a mixing model based on $\mathrm{NO}_{3}^{-}$and $\mathrm{Cl}^{-}$concentrations. Using this novel approach we were able to reconstruct the initial $\mathrm{NO}_{3}-\mathrm{N}$ concentration and $\mathrm{NO}_{3}-\mathrm{N} / \mathrm{Cl}^{-}$ratio at the point of entry to the groundwater system. Manure filtrate had total nitrogen (TN) of up to $1820 \mathrm{mg} \mathrm{L}^{-1}$, which was predominantly organic $\mathrm{N}$ and $\mathrm{NH}_{3}$. Groundwater had up to $85 \mathrm{mg} \mathrm{L}^{-1} \mathrm{TN}$, which was predominantly $\mathrm{NO}_{3}^{-}$. The addition of $\mathrm{NO}_{3}^{-}$to the local groundwater system from temporary manure piles and pens equalled or exceeded $\mathrm{NO}_{3}^{-}$additions from earthen manure storages at these sites. On-farm management of manure waste should therefore increasingly focus on limiting manure piles in direct contact with the soil and encourage storage in lined lagoons. Nitrate attenuation at both sites is attributed to a spatially variable combination of mixing and denitrification, but
\end{abstract}

is dominated by denitrification. Where identified, denitrification reduced agriculturally derived $\mathrm{NO}_{3}^{-}$concentrations by at least half and, in some wells, completely. Infiltration to groundwater systems in glacial sediments where $\mathrm{NO}_{3}^{-}$can be naturally attenuated is likely preferable to off-farm export via runoff or drainage networks, especially if local groundwater is not used for potable water supply.

\section{Introduction}

The contamination of soil and groundwater with nitrate from agricultural operations is a global water quality issue that has been extensively documented (Power and Schepers, 1989; Spalding and Exner, 1993; Rodvang and Simpkins, 2001; Galloway et al., 2008; Zirkle et al., 2016; Arauzo, 2017; Ascott et al., 2017). Leaching of nitrate $\left(\mathrm{NO}_{3}^{-}\right)$from animal waste or fertilisers can result in groundwater $\mathrm{NO}_{3}^{-}$concentrations that exceed drinking water guidelines and pose human health risks (Fan and Steinberg, 1996; Gulis et al., 2002; Yang et al., 2007). The discharge of high- $\mathrm{NO}_{3}^{-}$groundwater, runoff, or drainage can contaminate streams and lakes, resulting in eutrophication and ecosystem decline (Deutsch et al., 2006; Kaushal et al., 2011). In saturated groundwater systems with low oxygen concentrations, elevated $\mathrm{NO}_{3}^{-}$can be naturally attenuated by microbial denitrification (Wassenaar, 1995; Robertson et al., 1996; Smith et al., 1996; Tesoriero et al., 2000; Singleton et al., 2007). Concentrations of $\mathrm{NO}_{3}^{-}$ will also decrease along groundwater flow paths due to attenuation via dilution by hydrodynamic dispersion (referred 
to hereafter as mixing). Because of these natural attenuation mechanisms, infiltration to groundwater may be preferable to off-site drainage and runoff of nitrate-rich waters. Many agricultural operations are undertaken on fertile soils associated with glacial sediments (Spalding and Exner, 1993; Ernstsen et al., 2015; Zirkle et al., 2016). Understanding the sources and fate of agriculturally derived nitrate in groundwater systems in glacial sediments is therefore critical for managing impacts of human food production on the environment.

Identification of the sources and fate of $\mathrm{NO}_{3}^{-}$at agricultural operations can be challenging because of spatial and temporal variations in sources (e.g. earthen manure storage, temporary manure piles, or fertiliser) and heterogeneity in hydrogeologic systems (Spalding and Exner, 1993; Rodvang et al., 2004; Showers et al., 2008; Kohn et al., 2016). These spatial and temporal variations can result in complex subsurface solute distributions that are difficult to interpret using classical transect studies or numerical groundwater models (Green et al., 2010; Baily et al., 2011).

Groundwater containing significant agriculturally derived $\mathrm{NO}_{3}^{-}$also typically has elevated chloride $\left(\mathrm{Cl}^{-}\right)$concentrations (Saffigna and Keeney, 1977; Rodvang et al., 2004; Menció et al., 2016). Decreasing $\mathrm{NO}_{3}-\mathrm{N} / \mathrm{Cl}^{-}$(or $\mathrm{NO}_{3}^{-} / \mathrm{Cl}^{-}$) ratios have been used to define denitrification based on the assumption that $\mathrm{NO}_{3}^{-}$is reactive while $\mathrm{Cl}^{-}$is non-reactive (conservative), such that denitrification results in a decrease in the $\mathrm{NO}_{3}-\mathrm{N} / \mathrm{Cl}^{-}$ratio (Kimble et al., 1972; Weil et al., 1990; Liu et al., 2006; McCallum et al., 2008). However, $\mathrm{NO}_{3} \mathrm{~N} / \mathrm{Cl}^{-}$ratios can also change in response to mixing of groundwater with different $\mathrm{NO}_{3}-\mathrm{N} / \mathrm{Cl}^{-}$ratios or when groundwater sampling traverses hydraulically disconnected formations (Bourke et al., 2015b). If $\mathrm{NO}_{3}-\mathrm{N} / \mathrm{Cl}^{-}$ratios vary among potential sources and the $\mathrm{NO}_{3}-\mathrm{N} / \mathrm{Cl}^{-}$ratio at the point of entry to the groundwater system can be reconstructed, this information could be used to show that anthropogenic $\mathrm{NO}_{3}^{-}$at different locations within an aquifer is derived from the same or different sources.

The stable isotopes of $\mathrm{NO}_{3}^{-}\left(\delta^{15} \mathrm{~N}_{\mathrm{NO}_{3}}\right.$ and $\left.\delta^{18} \mathrm{O}_{\mathrm{NO}_{3}}\right)$ provide an alternative approach to characterising the source and fate of $\mathrm{NO}_{3}^{-}$in groundwater systems. In agricultural areas, multiple sources of $\mathrm{NO}_{3}^{-}$are common and could include precipitation, soil $\mathrm{NO}_{3}^{-}$, inorganic fertiliser, manure, and septic waste (Komor and Anderson, 1993; Liu et al., 2006; PasténZapata et al., 2014; Clague et al., 2015; Xu et al., 2015). While source identification is theoretically possible using $\delta^{15} \mathrm{~N}_{\mathrm{NO}_{3}}$ and $\delta^{18} \mathrm{O}_{\mathrm{NO}_{3}}$ (particularly with a dual-isotope approach), in practice this can be difficult due to geologic heterogeneity, overlapping source values, and the complexity of biologically mediated reactions (Aravena et al., 1993; Wassenaar, 1995; Mengis et al., 2001; Choi et al., 2003; Granger et al., 2008; Vavilin and Rytov, 2015; Xu et al., 2015).

$\mathrm{NO}_{3}^{-}$attenuation by denitrification in groundwater systems can be identified based on the characteristic enrichment of $\delta^{15} \mathrm{~N}_{\mathrm{NO}_{3}}$ and $\delta^{18} \mathrm{O}_{\mathrm{NO}_{3}}$. Numerous studies have made qualitative assessments that identified denitrification in ground- water using the stable isotope approach (Böttcher et al., 1990; Wassenaar, 1995; Singleton et al., 2007; Baily et al., 2011; Clague et al., 2015; Xu et al., 2015). Recently published papers have also used stable isotopic values of $\mathrm{NO}_{3}^{-}$ and water as the basis for mixing models in agricultural settings (Ji et al., 2017; Lentz and Lehersch, 2019). Isotopic fractionation effects can also allow for quantitative assessment of the proportion of substrate that has undergone a given reaction, if enrichment factors and source values are known; as in the case of evaporative loss of water, for example (Dogramaci et al., 2012). To date, there have been very few attempts to quantify denitrification using dual-isotope enrichment, largely due to uncertainty in source values and enrichment factors (Böttcher et al., 1990, Xue et al., 2009).

The only published calculations of the fraction of $\mathrm{NO}_{3}^{-}$remaining after denitrification the that we are aware of assumed a constant enrichment factor and the same isotopic source values across the field site (Otero et al., 2009). However, the enrichment factor will vary across a field site in response to reaction rates (Kendall and Aravena, 2000), and isotopic values of even the same type of source (e.g. manure) can vary substantially (Xue et al., 2009).

If the variation in source values and enrichment factors can be characterised from measured data then these uncertainties can be accounted for using a Monte Carlo approach (Joerin et al., 2002; Bourke et al., 2015a; Ji et al., 2017), thereby extending the application of the dual-isotope technique to allow for a robust quantitative assessment of denitrification in agricultural settings.

A synthesised analysis of stable isotopes of $\mathrm{NO}_{3}^{-}$with additional ionic tracers can further improve the assessment of $\mathrm{NO}_{3}^{-}$attenuation mechanisms and sources of $\mathrm{NO}_{3}^{-}$in agricultural settings (Showers et al., 2008; Vitòria et al., 2008; Xue et al., 2009; Xu et al., 2015; Ji et al., 2017). We hypothesise that if the amount of denitrification can be quantified based on $\delta^{15} \mathrm{~N}_{\mathrm{NO}_{3}}$ and $\delta^{18} \mathrm{O}_{\mathrm{NO}_{3}}$, then this estimate of the fraction of $\mathrm{NO}_{3}-\mathrm{N}$ removed through denitrification can be used to constrain a mixing model based on $\mathrm{NO}_{3}-\mathrm{N}$ and $\mathrm{Cl}^{-}$ concentrations. This novel approach allows for the ratio of $\mathrm{NO}_{3}-\mathrm{N} / \mathrm{Cl}^{-}$at the point of entry to the groundwater system to be reconstructed from measured $\mathrm{NO}_{3}^{-}$and $\mathrm{Cl}^{-}$concentrations (see Sect. 2.4). Where the $\mathrm{NO}_{3}-\mathrm{N} / \mathrm{Cl}^{-}$ratio varies between sources, this ratio can then be used to assess the source of the $\mathrm{NO}_{3}^{-}$in groundwater (e.g. temporary manure piles or feeding pens). These data can also then be used to estimate the initial concentrations of $\mathrm{NO}_{3}^{-}$and $\mathrm{Cl}^{-}$at the point of entry to the groundwater system and quantify attenuation by mixing.

In this study, we present the application of this approach at two confined feeding operations (CFOs) in Alberta, Canada, with differing lithologies and durations of operation (Fig. 1). Concentrations of $\mathrm{Cl}^{-}$and nitrogen species ( $\mathrm{N}$ species) and the stable isotopes of $\mathrm{NO}_{3}^{-}$were measured in groundwater samples collected from monitoring wells and continuous soil cores, as well as manure filtrate at both sites. These data were 


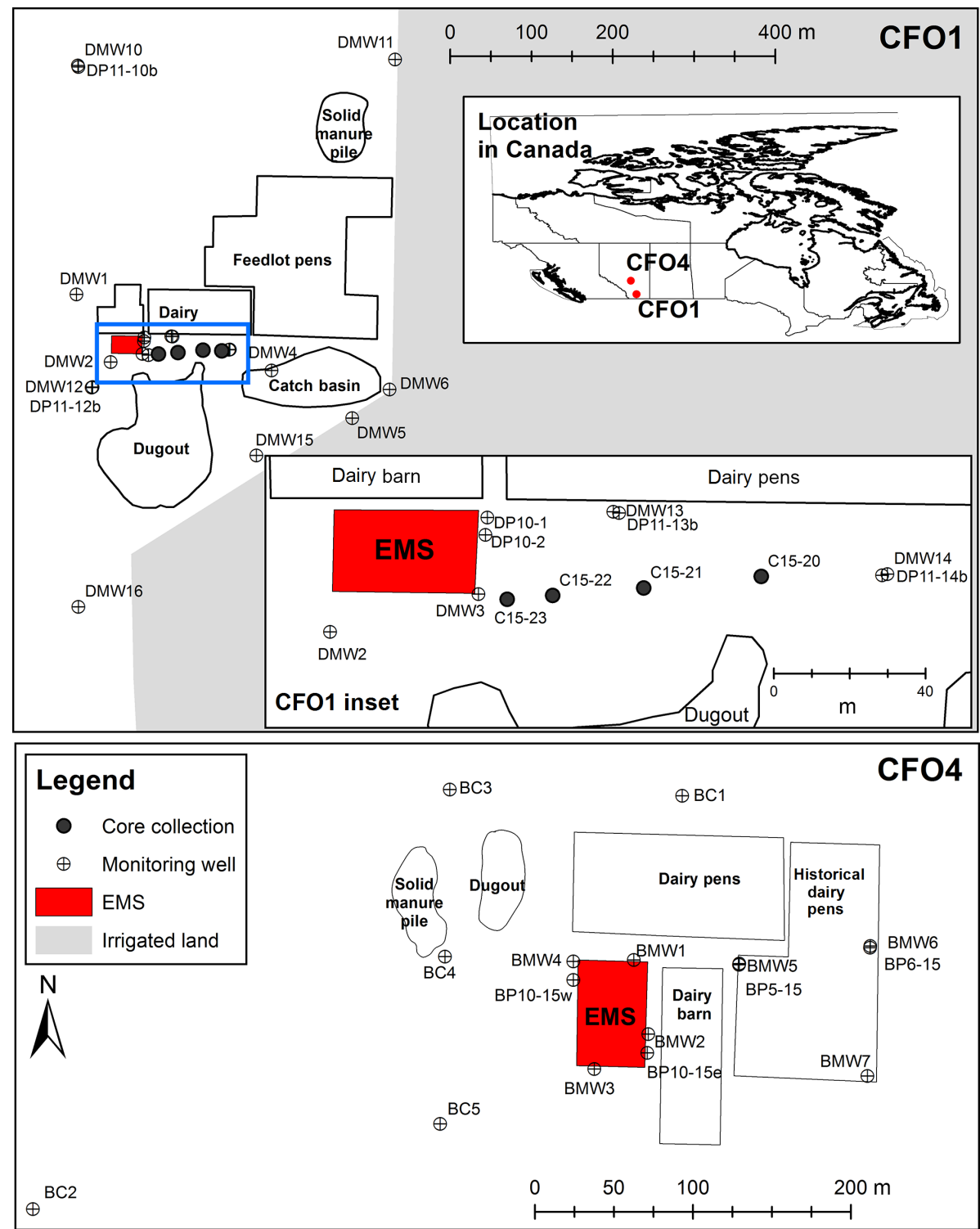

Figure 1. Map of study sites $\mathrm{CFO} 1$ and $\mathrm{CFO} 4$, showing locations of groundwater monitoring wells, core collection, earthen manure storages (EMSs), dairy and feedlot pens, manure piles, and irrigated land. Blue rectangle indicates extent of CFO1 inset.

interpreted to (1) assess the extent of agriculturally derived $\mathrm{NO}_{3}^{-}$in groundwater, (2) identify sources and initial concentrations of $\mathrm{NO}_{3}^{-}$at the point of entry to the groundwater system, and (3) assess mixing and denitrification as attenuation mechanisms at these sites.

\section{Materials and methods}

\subsection{Experimental sites}

This study was conducted using data from two of the five sites investigated by Alberta Agriculture and Forestry during an assessment of the impacts of livestock manure on groundwater quality (Lorenz et al., 2014). To the best of our knowl- edge (including discussions with farm operators) fertilisers have not been applied at either of these sites. As such, manure waste from livestock is assumed to be the sole source of agricultural nitrogen $(\mathrm{N})$ and elevated $\mathrm{NO}_{3}^{-}$concentrations in groundwater at these sites.

The first study site (CFO1) is located $25 \mathrm{~km}$ northeast of Lethbridge, Alberta (Fig. 1). Agricultural operations at this site were initiated with the construction of a dairy in 1928 , which has the capacity for 150 dairy cattle. A feedlot for beef cattle was added in 1960s along with an earthen manure storage (EMS) facility for storing liquid dairy manure (approx. $4 \mathrm{~m}$ deep) and a catch basin that receives surface water runoff. This feedlot was expanded in the 1980s to the 2000head capacity it was at the time of this study. There is also 
a dugout (or slough, a shallow wetland) on-site that receives local runoff and an irrigation drainage canal at the southern boundary of the property.

The second study site (CFO4) is located approximately $30 \mathrm{~km}$ north of Red Deer, Alberta, and $300 \mathrm{~km}$ north of CFO1. This dairy and associated EMS (approx. $6 \mathrm{~m}$ deep) were constructed in 1995 and the facility had 350 head of dairy cattle at the time of the study. Runoff will drain either to the small dugout in the northwest of the site, or the natural drainage features (ephemeral ponds or a creek approx. $1.5 \mathrm{~km}$ east).

\subsection{Sampling and instrumentation}

\subsubsection{Groundwater monitoring wells}

Groundwater samples were collected from water table wells and piezometers (hereafter both are referred to as wells) installed at both sites (Table 1). At CFO1, groundwater samples were collected from six individual water table wells (DMW1, DMW2, DMW3, DMW4, DMW5, DMW6) and eight sets of nested wells with one well screened at the water table and one well screened $20 \mathrm{~m}$ below ground (BG) (DP10-2 and DP10-1, DMW10 and DP11-10b, DMW11 and DP11-11b, DMW12 and DP11-12b, DMW13 and DP11-13b, DMW14 and DP11-14b, DMW15 and DP11-15b, and DMW16 and DP11-16b). Wells DP10-2 and DP10-1 were located directly adjacent to the EMS on the hydraulically down-gradient side. At $\mathrm{CFO} 4$, groundwater samples were collected from eight water table wells (BC1, BC2, BC3, BC4, BC5, BMW1, BMW3, BMW7) and four sets of nested wells, with wells screened across the water table and at $15 \mathrm{~m} \mathrm{BG}$. Two of these nests were located adjacent to the EMS (BMW2 and BP1015e, BMW4 and BP10-15w) and two were hydraulically down-gradient of the EMS (BMW5 and BP5-15, BMW6 and BP6-15).

Groundwater samples were collected for ion analysis $\left(\mathrm{Cl}^{-}\right.$and N species) quarterly between April 2010 and August 2015. All water samples were collected using a bailer after purging (1-3 casing volumes) and stored at $\leq 4{ }^{\circ} \mathrm{C}$ prior to analysis. Samples for $\delta^{15} \mathrm{~N}_{\mathrm{NO}_{3}}$ and $\delta^{18} \mathrm{O}_{\mathrm{NO}_{3}}$ were collected from wells at CFO1 on 1 January and 1 May 2013. Samples for $\delta^{15} \mathrm{~N}_{\mathrm{NO}_{3}}$ and $\delta^{18} \mathrm{O}_{\mathrm{NO}_{3}}$ at $\mathrm{CFO} 4$ were collected on 27 October 2014. Wells were purged prior to sample collection (1-3 casing volumes), and samples filtered into highdensity polyethylene (HDPE) bottles in the field and frozen until analysis.

Hydraulic heads in monitoring wells were determined using manual measurements (approximately monthly, 20102015). Hydraulic head response tests were conducted on the majority of the wells at the sites to determine hydraulic conductivity $(K)$ of the formation media surrounding the intake zone. These tests were either a slug test (water level decline after water addition) or bail test (water level recovery after water removal) depending on the location of the water level within the well at the time of testing. $K$ was determined from the hydraulic head responses using the method of Hvorslev (1951).

\subsubsection{Continuous core}

A continuous core was collected at CFO1 immediately adjacent to well DP11-13b on 1 May 2013 (Fig. 1). Additional core samples were collected from 1 to 5 June 2015 along a transect hydraulically down-gradient of the southeastern side of the EMS at CFO1, where hydrochemistry data suggested leakage from the EMS (see Sect. 3). During this 2015 drilling campaign, core samples were collected at four locations (DC15-20, DC15-21, DC15-22, DC15-23) to depths of up to $15 \mathrm{~m}$ below surface and distances of up to $100 \mathrm{~m}$ from the EMS between wells DMW3 and DP11-14.

Continuous core samples were retrieved using a hollow stem auger ( $1.5 \mathrm{~m}$ core lengths) with $0.3 \mathrm{~m}$ sub-samples collected at approximately $1 \mathrm{~m}$ intervals ensuring that visually consistent lithology could be sampled. Core samples for $\mathrm{Cl}^{-}$ were stored in Ziploc ${ }^{\mathrm{TM}}$ bags and kept cool until analysis. Core samples for $\mathrm{N}$-species analysis were stored in Ziploc bags filled with an atmosphere of argon $(99.9 \% \mathrm{Ar})$ to minimise oxidation and kept cool until analysis. Subsamples of each core (250-300 g) were placed under $50 \mathrm{MPa}$ pressure in a Carver Auto Series NE mechanical press with a $0.5 \mu \mathrm{m}$ filter placed at the base of the squeezing chamber, which was placed within an Ar atmosphere to minimise oxidation. A syringe was attached to the base of the apparatus and $15 \mathrm{~mL}$ of filtered pore water were collected for analyses within 3.5 to $6.0 \mathrm{~h}$ (Hendry et al., 2013).

\subsubsection{Liquid manure storages}

Samples of liquid manure slurry were collected directly from the EMS at both sites and the catch basin (containing local runoff from the feedlot) at CFO1 using a pipe and plunger apparatus to sample from approximately $0.5 \mathrm{~m}$ below the surface. The slurry collected was subsequently filtered $(0.45 \mu \mathrm{m})$ to separate the liquid and solid components. The water filtered from samples collected from the EMS or catch basin is hereafter referred to as manure filtrate.

\subsection{Laboratory analysis}

Groundwater samples from wells were analysed by Alberta Agriculture and Forestry (Lethbridge, Alberta). Concentrations of $\mathrm{Cl}^{-}$were determined using potentiometric titration of $\mathrm{H}_{2} \mathrm{O}$, with a detection limit of $5.0 \mathrm{mg} \mathrm{L}^{-1}$ and accuracy of $5 \%$ (APHA $4500-\mathrm{Cl}^{-} \mathrm{D}$ ). Concentrations of $\mathrm{NH}_{3}$ as $\mathrm{N}\left(\mathrm{NH}_{3}-\mathrm{N}\right), \mathrm{NO}_{3}^{-}$as $\mathrm{N}\left(\mathrm{NO}_{3}-\mathrm{N}\right)$, and $\mathrm{NO}_{2}^{-}$as $\mathrm{N}$ $\left(\mathrm{NO}_{2}-\mathrm{N}\right)$ were measured by air-segmented continuous-flow analysis (APHA 4500-NH3 G, APHA 4500-NO3 F). Total nitrogen $(\mathrm{TN})$ was determined by high temperature catalytic combustion and chemiluminescence detection using a Shimadzu TOC-V with attached TN unit (ASTM D8083- 
Table 1. Details of groundwater monitoring wells and continuous core collection at CFO1 and CFO4 (all screens installed at bottom of the well).

\begin{tabular}{|c|c|c|c|c|c|c|c|c|}
\hline Site & $\begin{array}{l}\text { Well/core } \\
\text { hole ID }\end{array}$ & Type $^{\mathrm{a}}$ & $\begin{array}{r}\text { Lateral } \\
\text { distance } \\
\text { from } \\
\mathrm{EMS}^{\mathrm{b}}(\mathrm{m})\end{array}$ & $\begin{array}{l}\text { Ground } \\
\text { elevation } \\
\text { (m a.s.1.) }\end{array}$ & $\begin{array}{r}\text { Total } \\
\text { depth }(\mathrm{m} \\
\text { below } \\
\text { ground })\end{array}$ & $\begin{array}{r}\text { Screen } \\
\text { length } \\
(\mathrm{m})\end{array}$ & $\begin{array}{l}\text { Lithology of } \\
\text { screened interval }\end{array}$ & $K\left(\mathrm{~m} \mathrm{~s}^{-1}\right)$ \\
\hline \multirow[t]{26}{*}{ CFO1 } & DMW1 & WTW & 60 & 869.7 & 5.0 & 4.0 & Sand & \multirow{3}{*}{$1.2 \times 10^{-7}$} \\
\hline & DMW2 & WTW & 10 & 867.2 & 6.0 & 4.0 & Sand & \\
\hline & DMW3 & WTW & 2 & 867.5 & 3.7 & 2.0 & Sand & \\
\hline & DMW4 & WTW & 160 & \multirow{3}{*}{866.4} & 4.2 & 4 & Sand & $1.3 \times 10^{-6}$ \\
\hline & DMW5 & WTW & 270 & & 6.8 & 4.0 & \multirow[t]{2}{*}{ Clayey sand } & \multirow[t]{2}{*}{$1.7 \times 10^{-5}$} \\
\hline & DMW6 & WTW & 310 & & 6.7 & 4 & & \\
\hline & DP10-1 & Piezo & 2 & 867.8 & 18.6 & 0.5 & Clay & $1.6 \times 10^{-9}$ \\
\hline & DP10-2 & Piezo & 2 & 867.9 & 8.0 & 1.5 & Sand & $3.6 \times 10^{-5}$ \\
\hline & DMW10 & WTW & 340 & 868.0 & 7.2 & 3.0 & Clay & $3.0 \times 10^{-7}$ \\
\hline & DP11-10b & Piezo & 340 & 868.0 & 20 & 0.5 & Clay & $2.2 \times 10^{-8}$ \\
\hline & DMW11 & WTW & 470 & 864.8 & 7.0 & 3.0 & Sand and clay & $4.2 \times 10^{-5}$ \\
\hline & DP11-11b & Piezo & 470 & & 20 & 0.5 & Clay & $6.3 \times 10^{-9}$ \\
\hline & DMW12 & WTW & 50 & 867.6 & 7.0 & 3.0 & Sand and clay & $7.4 \times 10^{-6}$ \\
\hline & DP11-12b & Piezo & 50 & 867.6 & 20.1 & 1.0 & Clay & $1.1 \times 10^{-8}$ \\
\hline & DMW13 & WTW & 35 & 867.1 & 7.0 & 3.0 & Sand & \multirow[t]{2}{*}{$8.9 \times 10^{-6}$} \\
\hline & DP11-13b & Piezo + core & 35 & 867.1 & 20.0 & 0.5 & Clay & \\
\hline & DMW14 & WTW & 105 & 865.7 & 7.0 & 3.0 & Clay & $5.7 \times 10^{-6}$ \\
\hline & DP11-14b & Piezo & 105 & 865.7 & 20.0 & 0.5 & Sand & $1.1 \times 10^{-6}$ \\
\hline & DMW15 & WTW & 185 & \multirow{8}{*}{866.0} & 7.0 & 3 & Clay & $2.4 \times 10^{-8}$ \\
\hline & DP11-15b & Piezo & 185 & & 20.0 & 0.5 & Clay & $1.4 \times 10^{-7}$ \\
\hline & DMW16 & WTW & 320 & & 6.0 & 3.0 & Sand and clay & - \\
\hline & DP11-16b & Piezo & 320 & & 20.0 & 0.5 & Clay & $3.2 \times 10^{-9}$ \\
\hline & DC15-20 & Core & 76 & & 15 & & & \\
\hline & DC15-21 & Core & 45 & & 10.5 & & & \\
\hline & DC15-22 & Core & 22 & & 12 & & & \\
\hline & DC15-23 & Core & 9 & & 15 & & & \\
\hline \multirow[t]{16}{*}{ CFO4 } & $\mathrm{BC} 1$ & WTW & 110 & 857.0 & 6.9 & 3.1 & Clay and sandstone & \\
\hline & $\mathrm{BC} 2$ & WTW & 365 & 859.4 & 7.0 & 3.1 & Clay and sandstone & $2.2 \times 10^{-7}$ \\
\hline & $\mathrm{BC} 3$ & WTW & 145 & 858.6 & 6.8 & 3.1 & Clay and sandstone & $1.3 \times 10^{-6}$ \\
\hline & $\mathrm{BC} 4$ & WTW & 95 & 858.8 & 5.9 & 3.0 & Clay and sandstone & $3.4 \times 10^{-6}$ \\
\hline & $\mathrm{BC} 5$ & WTW & 105 & 859.5 & 7.5 & 4.5 & Clay and sandstone & \\
\hline & BMW1 & WTW & 4 & 858.6 & 7.1 & 3.1 & Clay and sandstone & $4.3 \times 10^{-6}$ \\
\hline & BMW2 & WTW & 3 & 857.9 & 7.5 & 4.5 & Clay and sandstone & $8.5 \times 10^{-7}$ \\
\hline & BMW3 & WTW & 8 & 858.6 & 6.0 & 3.0 & Clay and sandstone & \multirow{3}{*}{$1.0 \times 10^{-5}$} \\
\hline & BMW4 & WTW & 14 & 858.0 & 7.5 & 4.8 & Clay and sandstone & \\
\hline & BMW5 & WTW & 60 & 858.0 & 7.5 & 4.5 & Clay and sandstone & \\
\hline & BP5-15 & Piezo & 60 & 858.1 & 15.3 & 1.5 & Sandstone & $1.0 \times 10^{-7}$ \\
\hline & BMW6 & WTW & 150 & 856.9 & 7.5 & 4.5 & Clay and sandstone & $4.0 \times 10^{-6}$ \\
\hline & BP6-15 & Piezo & 150 & 856.8 & 15.2 & 1.5 & Sandstone & $3.0 \times 10^{-6}$ \\
\hline & BMW7 & WTW & 140 & 856.7 & 7.5 & 4.5 & Clay and sandstone & $1.0 \times 10^{-6}$ \\
\hline & BP10-15e & Piezo & 4 & 858.2 & 14.9 & 1.5 & Sandstone & $2.9 \times 10^{-5}$ \\
\hline & BP10-15w & Piezo & 10 & 858.0 & 15.0 & 1.5 & Sandstone & $1.0 \times 10^{-5}$ \\
\hline
\end{tabular}

${ }^{a}$ WTW: water table well, Piezo: piezometer, Core: continuous core. ${ }^{\mathrm{b}}$ EMS: earthen manure storage. 
16). Total organic nitrogen (TON) was calculated by subtracting $\mathrm{NH}_{3}-\mathrm{N}, \mathrm{NO}_{3}-\mathrm{N}$, and $\mathrm{NO}_{2}-\mathrm{N}$ from TN. Bicarbonate $\left(\mathrm{HCO}_{3}^{-}\right)$was analysed by titration (APHA $2320 \mathrm{~B}$ ). Dissolved organic carbon (DOC) was analysed by a combustion infrared method (APHA 5310 B) using a Shimadzu TOC-V system. Manure filtrate was analysed by ALS (Saskatoon, Saskatchewan) using similar methods for $\mathrm{Cl}^{-}$ (APHA 4110 B), TN (RMMA A3769 3.3), $\mathrm{NO}_{3}+\mathrm{NO}_{2}$ as $\mathrm{N}$ (APHA 4500-NO3-F), $\mathrm{NH}_{3}-\mathrm{N}$ (APHA 4500-NH3 D), $\mathrm{HCO}_{3}^{-}$(APHA 2320), and DOC (APHA $5310 \mathrm{~B}$ ).

Pore-water samples squeezed from the continuous core were analysed at the University of Saskatchewan (Saskatoon, Canada) for $\mathrm{Cl}^{-}, \mathrm{NO}_{3}-\mathrm{N}$, and $\mathrm{NO}_{2}-\mathrm{N}$ using a Dionex IC25 ion chromatograph (IC) coupled to a Dionex As50 autosampler (EPA Method 300.1, accuracy and precision of 5.0\%) (Hautman and Munch, 1997). Ammonia as $\mathrm{N}\left(\mathrm{NH}_{3}-\mathrm{N}\right)$ was measured by Exova laboratories using the automated phenate method (APHA Standard 4500-NH3 G, detection limit of $0.025 \mathrm{mg} \mathrm{L}^{-1}$, accuracy of $2 \%$ of the measured concentration, and a precision of $5 \%$ of the measured concentration).

$\delta^{15} \mathrm{~N}_{\mathrm{NO}_{3}}$ and $\delta^{18} \mathrm{O}_{\mathrm{NO}_{3}}$ in groundwater samples (from wells and pore water from the continuous core) and manure filtrate were measured at the University of Calgary (Calgary, Alberta) using the denitrifier method (Sigman et al., 2001 ) with an accuracy and precision of $0.3 \%$ for $\delta^{15} \mathrm{~N}_{\mathrm{NO}_{3}}$ and $0.7 \%$ for $\delta^{18} \mathrm{O}_{\mathrm{NO}_{3}}$. Groundwater samples collected for $\mathrm{NO}_{3}^{-}$isotope analysis in January 2013 were also analysed for $\mathrm{NO}_{3}-\mathrm{N}$ by the University of Calgary (denitrifier technique, Delta + XL).

\subsection{Modelling approach}

\subsubsection{Quantification of denitrification based on $\delta^{15} \mathrm{~N}_{\mathrm{NO}_{3}}$ and $\delta^{18} \mathrm{O}_{\mathrm{NO}_{3}}$}

Nitrate in groundwater that has undergone denitrification is commonly reported as being identified by enrichment of $\delta^{15} \mathrm{~N}_{\mathrm{NO}_{3}}$ and $\delta^{18} \mathrm{O}_{\mathrm{NO}_{3}}$ with a slope of about 0.5 on a cross-plot (Clark and Fritz, 1997). However, published studies of denitrification in groundwater report slopes of up to 0.77 (Mengis et al., 1999; Fukada et al., 2003; Singleton et al., 2007). The relationship between isotopic enrichment of ${ }^{15} \mathrm{~N}_{\mathrm{NO}_{3}}$ and ${ }^{18} \mathrm{O}_{\mathrm{NO}_{3}}$ and the fraction of $\mathrm{NO}_{3}-\mathrm{N}$ remaining during denitrification can be described by a Rayleigh equation:

$R=R_{0} f_{\mathrm{d}}^{\left(\frac{1}{\beta}-1\right)}$

where $R_{0}$ is the initial isotope ratio (relative to the standard) of the $\mathrm{NO}_{3}^{-}\left(\delta^{18} \mathrm{O}_{\mathrm{NO}_{3}}\right.$ or $\left.\delta^{15} \mathrm{~N}_{\mathrm{NO}_{3}}\right), R$ is the isotopic ratio when fraction $f_{\mathrm{d}}$ of $\mathrm{NO}_{3}^{-}$remains, and $\beta$ is the kinetic fractionation factor (> 1) (Böttcher et al., 1990; Clark and Fritz, 1997; Otero et al., 2009; Xue et al., 2009). Kinetic fraction effects are commonly also expressed as the enrichment factor, $\varepsilon=\frac{1}{1000(\beta-1)}$. In the case of a constant enrich- ment factor, $f_{\mathrm{d}}$ can be calculated from measured $\delta^{15} \mathrm{~N}_{\mathrm{NO}_{3}}$ (or $\left.\delta^{18} \mathrm{O}_{\mathrm{NO}_{3}}\right)$, if the initial $\delta^{15} \mathrm{~N}_{\mathrm{NO}_{3}}\left(\delta^{15} \mathrm{~N}_{0}\right)$ is known;

$f_{\mathrm{d}}=\exp \left(\frac{\delta^{15} \mathrm{~N}_{\mathrm{NO}_{3}}-\delta^{15} \mathrm{~N}_{0}}{\varepsilon}\right)$.

The fraction of $\mathrm{NO}_{3}-\mathrm{N}$ removed from groundwater through denitrification is then given by $\left(1-f_{\mathrm{d}}\right)$. The concentration of $\mathrm{NO}_{3}-\mathrm{N}$ that would have been measured if mixing was the only attenuation mechanism $\left(\mathrm{NO}_{3}-\mathrm{N}_{\text {mix }}\right)$ can also be calculated by dividing the measured concentration by $f_{\mathrm{d}}$.

A subset of 20 samples with isotopic values of $\mathrm{NO}_{3}^{-}$indicative of denitrification were identified, and for each of these samples $f_{\mathrm{d}}$ (mean and standard deviation) was calculated from Eq. (2) using a Monte Carlo approach with 500 realizations. The distribution of $\varepsilon$ values was defined based on measured data. If the initial $\delta^{15} \mathrm{~N}_{\mathrm{NO}_{3}}$ is known, $\varepsilon$ for $\delta^{15} \mathrm{~N}_{\mathrm{NO}_{3}}$ $\left(\varepsilon_{15} \mathrm{~N}\right)$ can be determined from the slope of the linear regression line on a plot of $\ln \left(f_{\mathrm{d}}\right)$ vs. $\delta^{15} \mathrm{~N}_{\mathrm{NO}_{3}}$ (Böttcher et al., 1990). If the initial $\delta^{15} \mathrm{~N}_{\mathrm{NO}_{3}}$ and $f_{\mathrm{d}}$ are not known, as is the case here, $\varepsilon_{15} \mathrm{~N}$ can be determined from the slope of the regression line on a plot of $\ln \left(\mathrm{NO}_{3}-\mathrm{N}\right)$ vs. $\delta^{15} \mathrm{~N}_{\mathrm{NO}_{3}}$, which will be the same as on a plot of $\ln \left(f_{\mathrm{d}}\right)$ vs. $\delta^{15} \mathrm{~N}_{\mathrm{NO}_{3}}$. In situ variations in temperature and reaction rates may affect the enrichment factor (Kendall and Aravena, 2000) and this was accounted for by allowing for variation in $\varepsilon 1{ }_{15} \mathrm{~N}$ within the Monte Carlo analysis. The enrichment factor for $\delta^{18} \mathrm{O}_{\mathrm{NO}_{3}}$ $\left(\varepsilon{ }_{18} \mathrm{O}\right)$ was calculated by multiplying the $\delta^{15} \mathrm{~N}_{\mathrm{NO}_{3}}$ by a linear coefficient of proportionality determined for each CFO from the slope of the denitrification trend on an isotope cross-plot (see Sect. 3.2).

For each realisation, initial isotopic values $\left(\delta^{15} \mathrm{~N}_{0}\right.$ and $\left.\delta^{18} \mathrm{O}_{0}\right)$ were determined by Excel Solver such that the difference between $f_{\mathrm{d}}$ calculated from $\delta^{15} \mathrm{~N}_{\mathrm{NO}_{3}}$ and $\delta^{18} \mathrm{O}_{\mathrm{NO}_{3}}$ was minimised ( $<1 \%$ difference). The ranges of $\delta^{15} \mathrm{~N}_{0}$ and $\delta^{18} \mathrm{O}_{0}$ were limited based on measured data and literature values (see Sect. 3.2). This approach neglects the effect of mixing of groundwater with differing isotopic values and is valid if the concentration of $\mathrm{NO}_{3}^{-}$in the source is much greater than background concentrations such that the isotopic composition of $\mathrm{NO}_{3}^{-}$is dominated by the agriculturally derived end-member.

\subsubsection{Quantification of mixing and initial concentrations of $\mathrm{Cl}^{-}$and $\mathrm{NO}_{3}-\mathrm{N}$}

A binary mixing model that also accounts for decreasing $\mathrm{NO}_{3}-\mathrm{N}$ concentrations in response to denitrification was used to quantify $\mathrm{NO}_{3}^{-}$attenuation by mixing and estimate the initial concentrations of $\mathrm{Cl}^{-}$and $\mathrm{NO}_{3}-\mathrm{N}$. The measured concentration of $\mathrm{Cl}^{-}$was assumed to be a function of two end-members mixing, described by

$\mathrm{Cl}=f_{\mathrm{m}} \mathrm{Cl}_{\mathrm{i}}+\left(1-f_{\mathrm{m}}\right) \mathrm{Cl}_{\mathrm{b}}$, 
where $\mathrm{Cl}$ is the measured concentration of $\mathrm{Cl}^{-}$in the groundwater sample, $\mathrm{Cl}_{\mathrm{i}}$ is the concentration of $\mathrm{Cl}^{-}$at the initial point of entry of the agriculturally derived $\mathrm{NO}_{3}^{-}$to the groundwater system, $\mathrm{Cl}_{\mathrm{b}}$ is the concentration of $\mathrm{Cl}^{-}$in the background ambient groundwater, and $f_{\mathrm{m}}$ is the fraction of water in the sample from the source of agriculturally derived $\mathrm{Cl}^{-}$(and $\mathrm{NO}_{3}^{-}$) remaining in the mixture.

The concentration of $\mathrm{NO}_{3}-\mathrm{N}$ was also assumed to be a function of two end-members mixing but with an additional coefficient, $f_{\mathrm{d}}$ (the fraction of $\mathrm{NO}_{3}-\mathrm{N}$ remaining after denitrification), applied to account for denitrification. The measured $\mathrm{NO}_{3}-\mathrm{N}$ concentration was thus described by

$\mathrm{NO}_{3}-\mathrm{N}=f_{\mathrm{d}}\left(f_{\mathrm{m}} \mathrm{NO}_{3}-\mathrm{N}_{\mathrm{i}}+\left(1-f_{\mathrm{m}}\right) \mathrm{NO}_{3}-\mathrm{N}_{\mathrm{b}}\right)$,

where $\mathrm{NO}_{3}-\mathrm{N}$ is the concentration of $\mathrm{NO}_{3}-\mathrm{N}$ measured in the groundwater sample, $\mathrm{NO}_{3}-\mathrm{N}_{\mathrm{i}}$ is the concentration of $\mathrm{NO}_{3}-\mathrm{N}$ in the source of agriculturally derived $\mathrm{NO}_{3}^{-}$ at the initial point of entry to the groundwater system, and $\mathrm{NO}_{3}-\mathrm{N}_{\mathrm{b}}$ is the concentration of $\mathrm{NO}_{3}-\mathrm{N}$ in the background ambient groundwater. This mixing calculation was only conducted on samples for which $\mathrm{NO}_{3}^{-}$dominated total$\mathrm{N}\left(\mathrm{NH}_{3}-\mathrm{N}<10 \%\right.$ of $\left.\mathrm{NO}_{3}-\mathrm{N}\right)$ so that nitrification of $\mathrm{NH}_{3}$ could be neglected.

If $\mathrm{Cl}_{\mathrm{i}}$ is much greater than $\mathrm{Cl}_{\mathrm{b}}$ and $\mathrm{NO}_{3}-\mathrm{N}_{\mathrm{i}}$ is much greater than $\mathrm{NO}_{3}-\mathrm{N}_{\mathrm{b}}$, then $f_{\mathrm{m}}$ is insensitive to background concentrations and these terms can be neglected (see Sect. 4.2 for further discussion of this assumption). In this case, Eqs. (3) and (4) reduce to

$\mathrm{Cl}=f_{\mathrm{m}} \mathrm{Cl}_{\mathrm{i}}$,

$\mathrm{NO}_{3}-\mathrm{N}=f_{\mathrm{d}}\left(f_{\mathrm{m}} \mathrm{NO}_{3}-N_{\mathrm{i}}\right)$.

Solving Eq. (6) for $f_{\mathrm{m}}$ and substituting into Eq. (5) yields

$\frac{\mathrm{NO}_{3}-\mathrm{N}_{\mathrm{i}}}{\mathrm{Cl}_{\mathrm{i}}}=\frac{1}{f_{\mathrm{d}}} \frac{\mathrm{NO}_{3}-\mathrm{N}}{\mathrm{Cl}}$.

Thus, for each groundwater sample, the ratio of $\mathrm{NO}_{3}-\mathrm{N} / \mathrm{Cl}^{-}$at the initial point of entry of the agriculturally derived $\mathrm{NO}_{3}^{-}$to the groundwater system $\left(\frac{\mathrm{NO}_{3}-\mathrm{N}_{\mathrm{i}}}{\mathrm{Cl}_{\mathrm{i}}}\right)$ can be simply calculated using measured concentrations, and $f_{\mathrm{d}}$ estimated from $\mathrm{NO}_{3}^{-}$isotope data. This provides a relatively simple method to identify agriculturally derived $\mathrm{NO}_{3}^{-}$from different sources (e.g. EMS vs. manure piles) if they have different $\mathrm{NO}_{3}-\mathrm{N} / \mathrm{Cl}^{-}$ratios. Estimated $\mathrm{Cl}_{\mathrm{i}}$ and $\mathrm{NO}_{3}-\mathrm{N}_{\mathrm{i}}$ are reported as the mid-range value with uncertainty described by the minimum and maximum values. These initial concentrations are at the water table for top-down inputs, or at the saturated point of contact between the EMS and the aquifer for leakage from the EMS. This analysis assumes that a sampled water parcel consists of water with agriculturally derived $\mathrm{NO}_{3}^{-}$that entered the aquifer from one source at one point in time and space and has since mixed with natural ambient groundwater. Any $\mathrm{NO}_{3}^{-}$produced during nitrification after the anthropogenic source water enters the aquifer is implicitly included in $\mathrm{NO}_{3}-\mathrm{N}_{\mathrm{i}}$. The error in $\frac{\mathrm{NO}_{3}-\mathrm{N}_{\mathrm{i}}}{\mathrm{Cl}_{\mathrm{i}}^{-}}$was assumed to be dominated by error in the estimated $f_{\mathrm{d}}$, with the measurement error in $\mathrm{NO}_{3}-\mathrm{N}$ and $\mathrm{Cl}^{-}$considered negligible.

The initial concentrations of the agriculturally derived $\mathrm{NO}_{3}^{-}$source $\left(\mathrm{NO}_{3}-\mathrm{N}_{\mathrm{i}}\right.$ and $\left.\mathrm{Cl}_{\mathrm{i}}\right)$ were estimated by simultaneously solving Eqs. (5) and (6) using Excel Solver (GRG nonlinear). The absolute minimum values of $\mathrm{NO}_{3}-\mathrm{N}_{\mathrm{i}}$ and $\mathrm{Cl}_{\mathrm{i}}$ were defined by measured concentrations (e.g. if $\mathrm{Cl}_{\mathrm{i}}=\mathrm{Cl}$, $f_{\mathrm{m}}=1$ ). Maximum values of $\mathrm{NO}_{3}-\mathrm{N}_{\mathrm{i}}$ and $\mathrm{Cl}_{\mathrm{i}}$ were defined based on measured concentrations of $\mathrm{NO}_{3}-\mathrm{N}$ and $\mathrm{Cl}^{-}$in groundwater and manure filtrate $\left(\mathrm{NO}_{3}-\mathrm{N} \leq 150 \mathrm{mg} \mathrm{L}^{-1}\right.$ and $\mathrm{Cl}^{-} \leq 1300 \mathrm{mg} \mathrm{L}^{-1}$; see Sect. 3.2). These maximum values of $\mathrm{NO}_{3}-\mathrm{N}_{\mathrm{i}}$ and $\mathrm{Cl}_{\mathrm{i}}$ correspond to the minimum $f_{\mathrm{m}}$. The value of $f_{\mathrm{d}}$ was assumed to be the mean $f_{\mathrm{d}}$ estimated from $\mathrm{NO}_{3}^{-}$isotopes using Eq. (2), and $\frac{\mathrm{NO}_{3}-\mathrm{N}_{\mathrm{i}}}{\mathrm{Cl}_{\mathrm{i}}}$ was required to be within 1 standard deviation of the estimate from Eq. (7).

The resulting estimates of $f_{\mathrm{m}}$ are reported as the midrange, with uncertainty described by the minimum and maximum values. Larger values of $f_{\mathrm{m}}$ indicate less mixing (a shorter path for advection-dispersion) and suggest a source close to the well. Smaller values of $f_{\mathrm{m}}$ indicate extensive mixing (a longer path for advection-dispersion) and suggest a source further away from the well. The relative contributions of mixing and denitrification to $\mathrm{NO}_{3}^{-}$attenuation at each site were evaluated by comparing $f_{\mathrm{m}}$ and $f_{\mathrm{d}}$ for each sample. This analysis was conducted using isotope values from the samples collected on 1 May 2013 at CFO1, which were combined with the $\mathrm{Cl}^{-}$and $\mathrm{NO}_{3}-\mathrm{N}$ data from 6 June 2013. At CFO4, results from stable isotopes collected on 27 October 2014 were combined with $\mathrm{Cl}^{-}$and $\mathrm{NO}_{3}-\mathrm{N}$ data collected on 7 October 2014.

\section{Results}

\subsection{Site hydrogeology}

\subsubsection{CFO1}

The geology at CFO1 consists of clay and clay-till interspersed with sand layers of varying thickness to the maximum depth of investigation ( $20 \mathrm{~m} \mathrm{BG}$, bedrock not encountered). Hydraulic conductivities $(K)$ calculated from slug tests on wells ranged from $1.2 \times 10^{-7}$ to $4.2 \times 10^{-5} \mathrm{~m} \mathrm{~s}^{-1}$ $(n=10)$ for sand, $1.1 \times 10^{-8}$ to $2.8 \times 10^{-8} \mathrm{~m} \mathrm{~s}^{-1}(n=2)$ for clay-till, and $1.6 \times 10^{-9}$ to $3.0 \times 10^{-7} \mathrm{~m} \mathrm{~s}^{-1}(n=8)$ for clay. Depth to the water table throughout the study site ranged from $0.5 \mathrm{~m}$ at DMW14 to $3.8 \mathrm{~m}$ at DMW11. Seasonal water table variations were about $0.5 \mathrm{~m}$ with no obvious change in the annual average during the 6-year measurement period. Water table elevation was highest at DMW10 and DMW1 on the west side of the site and lowest at DMW11 on the northeast side of the site (see Supplement). Measured heads indicate groundwater flow from the vicinity of 
the EMS to the northeast and southeast. Mean horizontal hydraulic gradients at the water table ranged from $4.4 \times 10^{-3}$ to $1.4 \times 10^{-2} \mathrm{~m} \mathrm{~m}^{-1}$. Vertical gradients were predominantly downward in the upper $20 \mathrm{~m}$ of the profile (mean gradients ranging from $1.8 \times 10^{-3}$ to $0.18 \mathrm{~m} \mathrm{~m}^{-1}$ ), with the exception of DMW11 where the vertical gradient was upward (mean gradient $-2.8 \times 10^{-2} \mathrm{~m} \mathrm{~m}^{-1}$ ). Using the geometric mean $K$ for the sand $\left(5.0 \times 10^{-6} \mathrm{~m} \mathrm{~s}^{-1}\right)$ and a lateral head gradient of $1.4 \times 10^{-2} \mathrm{~m} \mathrm{~m}^{-1}$ yields a specific discharge (Darcy flux, $q$ ) of $2.2 \mathrm{~m} \mathrm{yr}^{-1}$. Assuming an effective porosity of 0.3 (Rodvang et al., 1998), the average linear velocity $(\bar{v})$ is $7.4 \mathrm{~m} \mathrm{yr}^{-1}$. This suggests that, in the absence of attenuation by mixing or denitrification, agriculturally derived $\mathrm{NO}_{3}^{-}$ could have been transported through the groundwater system by advection about $400 \mathrm{~m}$ since 1960 and $630 \mathrm{~m}$ since 1930 .

\subsubsection{CFO4}

The geology at CFO4 consists of about $5 \mathrm{~m}$ of clay (with minor till) underlain by sandstone, to the maximum depth investigated (20 m BG). Hydraulic conductivities measured using slug tests on wells were $1.0 \times 10^{-8}$ to $1.0 \times 10^{-5} \mathrm{~m} \mathrm{~s}^{-1}$ $(n=12)$ for the clay and sandstone (many shallow wells were screened across the clay-till and into the sandstone) and $1.0 \times 10^{-5}$ to $2.9 \times 10^{-5} \mathrm{~m} \mathrm{~s}^{-1}(n=4)$ for the sandstone. The depth to water table ranged from 1.0 to $3.4 \mathrm{~m}$, increasing from west to east across the study site. Seasonal water table variations were on the order of $1.5 \mathrm{~m}$ with water table declines on the order of $0.3 \mathrm{~m} \mathrm{yr}^{-1}$. The horizontal hydraulic gradient was consistently from west to east, with a mean gradient at the water table of $3.9 \times 10^{-3} \mathrm{~m} \mathrm{~m}^{-1}$ between BC2 and BMW2 and $4.3 \times 10^{-3} \mathrm{~m} \mathrm{~m}^{-1}$ between BMW2 and BMW7. Vertical hydraulic gradients were $4.2 \times 10^{-2}$ to $4.6 \times 10^{-2} \mathrm{~m} \mathrm{~m}^{-1}$ downward. Using the geometric mean $K$ for the site $\left(2.9 \times 10^{-5} \mathrm{~m} \mathrm{~s}^{-1}\right)$ and a lateral head gradient of $4.3 \times 10^{-3} \mathrm{~m} \mathrm{~m}^{-1}$ yields a $q$ of $0.4 \mathrm{~m} \mathrm{yr}^{-1}$. Assuming an effective porosity of 0.3 yields a $\bar{v}$ of $1.3 \mathrm{~m} \mathrm{yr}^{-1}$. These values suggest that, in the absence of attenuation by mixing or denitrification, anthropogenic $\mathrm{NO}_{3}^{-}$could have been transported through the groundwater systems about $10 \mathrm{~m}$ by advection between 1995 and the time of sampling.

\subsection{Values and evolution of stable isotopes of nitrate}

The range of isotopic values of $\mathrm{NO}_{3}^{-}$in groundwater was similar at both sites (Fig. 2). At CFO1, $\delta^{18} \mathrm{O}_{\mathrm{NO}_{3}}$ ranged from -5.9 to $20.1 \%$ and $\delta^{15} \mathrm{~N}_{\mathrm{NO}_{3}}$ from -5.2 to $61.0 \%$. At CFO4, $\delta^{18} \mathrm{O}_{\mathrm{NO}_{3}}$ ranged from -1.9 to $31.6 \%$ and $\delta^{15} \mathrm{~N}_{\mathrm{NO}_{3}}$ from -1.3 to $70.5 \%$. The isotopic values of $\delta^{18} \mathrm{O}_{\mathrm{NO}_{3}}$ in groundwater are commonly assumed to be derived from a mix of a one-third atmospheric-derived oxygen $(+23.5 \%)$ and two-thirds water-derived oxygen (Xue et al., 2009). Given the average $\delta^{18} \mathrm{O}_{\mathrm{H}_{2} \mathrm{O}}$ for both sites $(-16 \%$; see Supplement), a one-third atmospheric two-thirds groundwater mix would result in a $\delta^{18} \mathrm{O}_{\mathrm{NO}_{3}}$ of $-3.7 \%$. Ma- nure filtrate from the EMS at CFO1 had $\delta^{15} \mathrm{~N}_{\mathrm{NO}_{3}}$ ranging from 0.4 to $5.0 \%$ and $\delta^{18} \mathrm{O}_{\mathrm{NO}_{3}}$ ranging from 7.1 to $19.0 \%$. A curve showing the co-evolution of $\delta^{18} \mathrm{O}_{\mathrm{NO}_{3}}$ (mixing of atmospheric $\delta^{18} \mathrm{O}$ with groundwater-derived $\delta^{18} \mathrm{O}$ ) and $\delta^{15} \mathrm{~N}_{\mathrm{NO}_{3}}$ (Rayleigh distillation, $\beta=1.005$ ) during nitrification is shown in Fig. 2. Isotopic values in DMW3, where direct leakage from the EMS was evident, are consistent with partial nitrification following this trend of isotopic evolution $\left(\delta^{18} \mathrm{O}_{\mathrm{NO}_{3}}\right.$ of $-1.2 \%$ and $\delta^{15} \mathrm{~N}_{\mathrm{NO}_{3}}$ of $7.8 \%$ ).

At both sites, co-enrichment of $\delta^{18} \mathrm{O}_{\mathrm{NO}_{3}}$ and $\delta^{15} \mathrm{~N}_{\mathrm{NO}_{3}}$ characteristic of denitrification was evident in some samples (slopes of 0.42 and 0.72 in Fig. 2a). At CFO1, this includes samples from DP10-2, DMW5, DMW11, DMW12, DP11-12b, and DMW13 (and associated core) and some pore water from cores DC15-22 and DC15-23. These samples had $\mathrm{NO}_{3}-\mathrm{N}$ concentrations of 0.6 to $23.7 \mathrm{mg} \mathrm{L}^{-1}, \delta^{18} \mathrm{O}_{\mathrm{NO}_{3}}$ ranging from 4.8 to $20.6 \%$, and $\delta^{15} \mathrm{~N}_{\mathrm{NO}_{3}}$ ranging from 22.9 to $61.3 \%$. At CFO4, samples exhibiting evidence of denitrification were from BMW2, BMW5, BMW6, BMW7, and $\mathrm{BC} 4$. These samples had $\mathrm{NO}_{3}-\mathrm{N}$ concentrations ranging from 0.4 to $35.1 \mathrm{mg} \mathrm{L}^{-1}, \delta^{18} \mathrm{O}_{\mathrm{NO}_{3}}$ ranging from 1.6 to $22.1 \%$, and $\delta^{15} \mathrm{~N}_{\mathrm{NO}_{3}}$ ranging from 20.9 to $70.1 \%$. Although the isotopic values of DMW5 suggest enrichment by denitrification, the data plot away from the rest of the CFO1 data and close to the denitrification trend at CFO4 (Fig. 2), suggesting these samples were affected by some other process (possibly mixing or nitrification); therefore, $f_{\mathrm{d}}$ was not calculated. Also, well DMW3, which clearly receives leakage from the EMS, did not contain substantial $\mathrm{NO}_{3}-\mathrm{N}$ and so $f_{\mathrm{d}}$ was not calculated.

In the Monte Carlo analysis the potential range of original isotopic values of the $\mathrm{NO}_{3}^{-}$source prior to denitrification $\left(\delta^{15} \mathrm{~N}_{0}\right.$ and $\left.\delta^{18} \mathrm{O}_{0}\right)$ varied from 5 to $27 \%$ for $\delta^{15} \mathrm{~N}_{\mathrm{NO}_{3}}$ and from -2 to $7 \%$ ofor $\delta^{18} \mathrm{O}_{\mathrm{NO}_{3}}$ based on isotopic values measured during this study (Fig. 2a). These values are consistent with literature values for manure-sourced $\mathrm{NO}_{3}^{-}$, which report $\delta^{15} \mathrm{~N}_{\mathrm{NO}_{3}}$ ranging from 5 to $25 \%$ and $\delta^{18} \mathrm{O}_{\mathrm{NO}_{3}}$ ranging from -5 to $5 \%$ (Wassenaar, 1995; Wassenaar et al., 2006; Singleton et al., 2007; McCallum et al., 2008; Baily et al., 2011). $\varepsilon_{15} \mathrm{~N}$ was defined by a normal distribution with a mean of $-10 \%$ and standard deviation of $2.5 \%$ (Fig. 2b). At CFO1, the coefficient of proportionality between the enrichment factor of $\delta^{15} \mathrm{~N}_{\mathrm{NO}_{3}}$ and $\delta^{18} \mathrm{O}_{\mathrm{NO}_{3}}$ was described by a normal distribution with mean of 0.72 and standard deviation of 0.05 . At CFO4, the coefficient of proportionality was also described by a normal distribution with a mean of 0.42 and standard deviation of 0.035 (see Fig. 2a). These enrichment factors are consistent with values from denitrification studies that report $\varepsilon_{15 \mathrm{~N}}$ ranging from -4.0 to $-30.0 \%$ and $\varepsilon_{18} \mathrm{O}$ ranging from -1.9 to $-8.9 \%$ (Vogel et al., 1981; Mariotti et al., 1988; Böttcher et al., 1990; Spalding and Parrott, 1994; Mengis et al., 1999; Pauwels et al., 2000; Otero et al., 2009). 

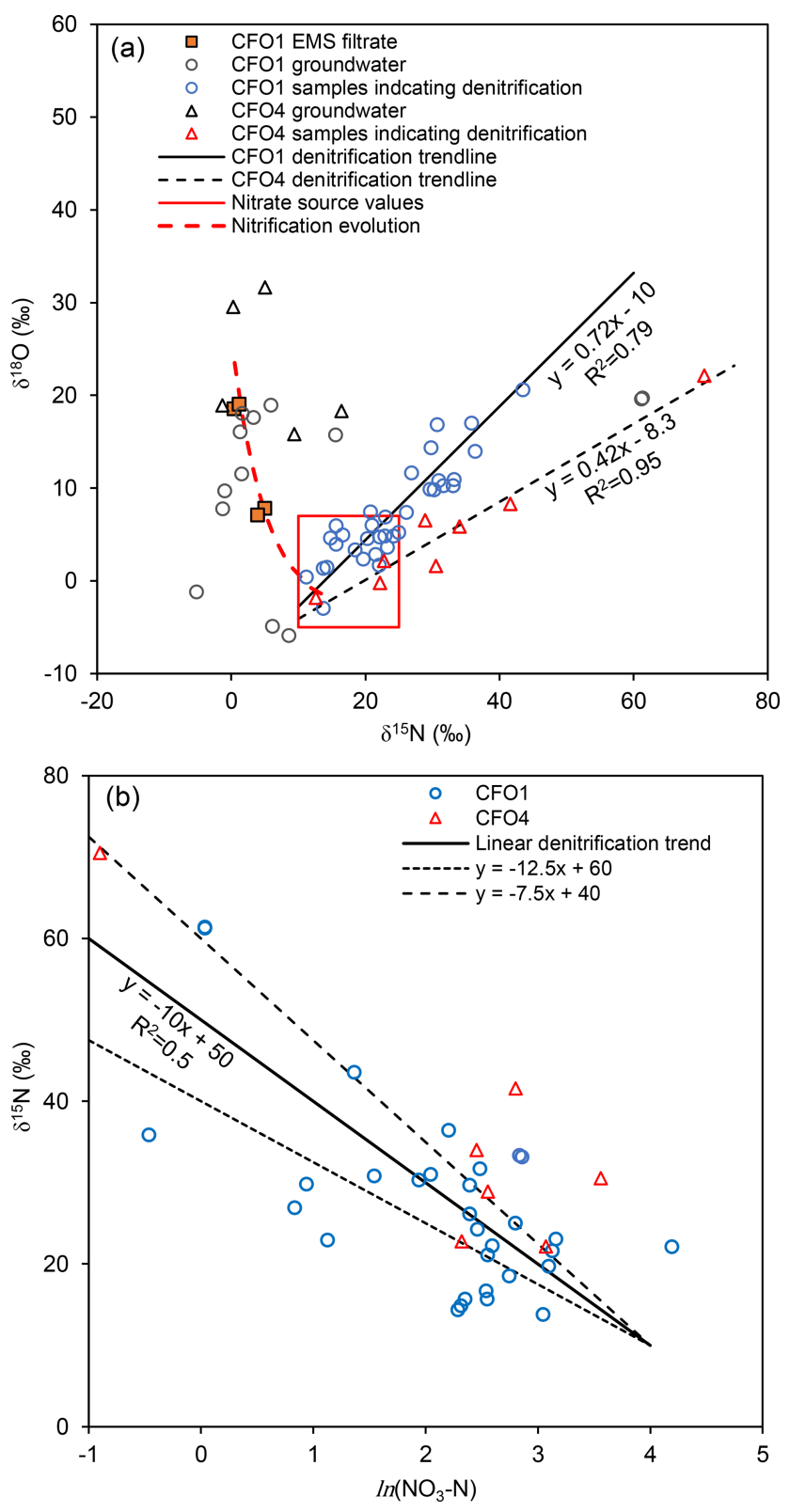

Figure 2. (a) Cross-plot of stable isotopes of nitrate at CFO1 and $\mathrm{CFO} 4$ showing hypothetical nitrification trend, boundary of manure-sourced $\mathrm{NO}_{3}^{-}$values and linear enrichment trends associated with denitrification. (b) Enrichment of $\delta^{15} \mathrm{~N}_{\mathrm{NO}_{3}}$ during denitrification (only samples within source region and with evidence of denitrification are shown); dashed lines represent \pm 1 SD of enrichment factor $(\varepsilon=-10)$.

\subsection{Distribution and sources of agricultural nitrate in groundwater}

At both sites TN concentrations in filtrate from the EMS and catch basin were generally an order of magnitude larger than concentrations in groundwater (Table 2). The one exception is well DMW3 at CFO1, which intercepted direct leakage from the EMS (see Sect. 3.3.1 for further discussion of this well). The dominant form of $\mathrm{N}$ differed between manure filtrate and groundwater. In the EMS filtrate, $\mathrm{N}$ was predominately organic $\mathrm{N}$ (TON up to $71 \%$ ) or $\mathrm{NH}_{3}-\mathrm{N}$ (up to $90 \%$ ), with $\mathrm{NO}_{x}-\mathrm{N}<0.1 \%$ of $\mathrm{TN}$. In the catch basin at CFO1 TON was $>99 \%$ of TN. In groundwater TN concentrations ranged from $<0.25$ to $84.6 \mathrm{mg} \mathrm{L}^{-1}$, and this $\mathrm{N}$ was predominantly $\mathrm{NO}_{3}^{-}$(again, with the exception of DMW3).

\subsubsection{CFO1}

Agriculturally derived $\mathrm{NO}_{3}^{-}$was generally restricted to the upper $20 \mathrm{~m}$ (or less) at CFO1 $\left(\mathrm{NO}_{3}-\mathrm{N} \leq 0.2 \mathrm{mg} \mathrm{L}^{-1}\right.$ and $\mathrm{Cl}^{-} \leq 57 \mathrm{mg} \mathrm{L}^{-1}$ in seven wells screened at $20 \mathrm{~m}$ ). The one exception was DP11-12b, which had up to $4.1 \mathrm{mg} \mathrm{L}^{-1}$ of $\mathrm{NO}_{3}-\mathrm{N}$. The southeast portion of the site also does not appear to have been significantly contaminated by agriculturally derived $\mathrm{NO}_{3}^{-}$, with $\mathrm{NO}_{3}-\mathrm{N}$ concentrations $<1 \mathrm{mg} \mathrm{L}^{-1}$ in five water table wells (DMW4, DMW6, DMW14, DMW15, DMW16). In DMW6, $\mathrm{Cl}^{-}$and TN concentrations were elevated (see Supplement) but $\mathrm{NO}_{3}-\mathrm{N}$ concentrations were $<2 \mathrm{mg} \mathrm{L}^{-1}$. Collectively, these data suggest the catch basin is not a significant source of $\mathrm{NO}_{3}^{-}$to the groundwater at this site.

Leakage of manure slurry from the EMS at CFO1 is clearly indicated by the data from DMW3, which feature the highest concentrations of $\mathrm{TN}$ in groundwater (up to $548 \mathrm{mg} \mathrm{L}^{-1}$ ) and elevated $\mathrm{Cl}^{-}, \mathrm{HCO}_{3}^{-}$, and $\mathrm{DOC}$ in concentrations similar to EMS manure filtrate (see Supplement). Nevertheless, $\mathrm{NO}_{3}-\mathrm{N}$ concentrations in this well were consistently low $\left(1.1 \pm 2.7 \mathrm{mg} \mathrm{L}^{-1}, n=22\right)$. The potential for nitrification in the vicinity of this well is indicated by $\mathrm{NO}_{2}-\mathrm{N}$ production $\left(2.7 \pm 8.3 \mathrm{mg} \mathrm{L}^{-1}, n=22\right)$. However, the data demonstrate that only a small proportion of the $\mathrm{NH}_{3}-\mathrm{N}$ in DMW3 (373.4 $\pm 79.4 \mathrm{mg} \mathrm{L}^{-1}, n=22$ ) could have been converted to $\mathrm{NO}_{3}^{-}$within the subsurface $\left(\mathrm{NO}_{3}-\mathrm{N}\right.$ in groundwater $\left.\leq 66 \mathrm{mg} \mathrm{L}^{-1}\right)$. Further work is required to assess the importance of cation exchange as an attenuation mechanism for direct leakage from the EMS at this site.

Contamination by agricultural $\mathrm{NO}_{3}^{-}$that exceeds the drinking water guidelines $\left(\mathrm{NO}_{3}-\mathrm{N}>10 \mathrm{mg} \mathrm{L}^{-1}\right)$ was observed in four wells (DMW1, DMW11, DMW13, and DP102) and in the continuous core (DC15-23) (Fig. 3). DMW2 and DMW12 also had $\mathrm{NO}_{3}-\mathrm{N}$ concentrations that were elevated but did not exceed the drinking water guideline ( $\leq$ $3.7 \mathrm{mg} \mathrm{L}^{-1}$ ). Given the evidence of partial nitrification in DMW3 (and low $\mathrm{NO}_{3}-\mathrm{N}$ concentrations), the $\mathrm{NO}_{3}-\mathrm{N} / \mathrm{Cl}^{-}$ ratio of contamination from the EMS was assumed to be best represented by DP10-2, which is located directly downgradient of the EMS. Data for this well indicate values of $\mathrm{NO}_{3}-\mathrm{N} / \mathrm{Cl}^{-}$predominantly ranging from 0.1 to 0.3 with $\mathrm{NO}_{3}-\mathrm{N}_{\mathrm{i}} / \mathrm{Cl}_{\mathrm{i}}$ estimated at $0.3 \pm 0.13$ (Fig. 4).

The maximum $\mathrm{NO}_{3}-\mathrm{N}$ concentration in groundwater at CFO1 (66.4 $\left.\mathrm{mg} \mathrm{L}^{-1}\right)$ was measured in core sample DC1523 (clay at $2 \mathrm{mb}$ b.g.l., $7 \mathrm{~m}$ hydraulically down-gradient of 
Table 2. Range of measured concentrations of $\mathrm{TN}, \mathrm{NH}_{3}-\mathrm{N}, \mathrm{NO}_{x}-\mathrm{N}\left(\mathrm{NO}_{2}-\mathrm{N}+\mathrm{NO}_{3}-\mathrm{N}\right)$, and TON at each study site. At CFO1 results from monitoring well DMW3 are presented separately because values in this well differed substantially from all other wells.

\begin{tabular}{llrrrr}
\hline Site & N pool & $\begin{array}{r}\mathrm{TN} \\
\left(\mathrm{mg} \mathrm{L}^{-1}\right)\end{array}$ & $\begin{array}{r}\mathrm{NH}_{3}-\mathrm{N} \\
\left(\mathrm{mg} \mathrm{L}^{-1}\right)\end{array}$ & $\begin{array}{r}\mathrm{NO}_{x}-\mathrm{N} \\
\left(\mathrm{mg} \mathrm{L}^{-1}\right)\end{array}$ & $\begin{array}{r}\mathrm{TON} \\
\left(\mathrm{mg} \mathrm{L}^{-1}\right)\end{array}$ \\
\hline CFO1 & EMS & $550-1820$ & $275-747$ & $<0.1-0.4$ & $73-1301$ \\
& Catch basin & $200-1440$ & $2.5-7.3$ & $<0.1$ & $196-1437$ \\
& DMW3 & $278-548$ & $219-479$ & $<0.1-50^{\mathrm{a}}$ & $31.3-73.9$ \\
& Other monitoring wells & $<0.25-33.4$ & $<0.05-2.9$ & $<0.1-31.4^{\mathrm{b}}$ & $<0.2-3.7$ \\
\hline CF04 & EMS & $1000-1240$ & $724-747$ & $0.25-0.29$ & $275-492$ \\
& Monitoring wells & $<0.25-84.6$ & $<0.05-0.23$ & $<0.1-80.4$ & $<0.2-13.9$ \\
\hline
\end{tabular}

${ }^{\text {a }} \mathrm{NO}_{x}-\mathrm{N}$ of $50 \mathrm{mg} \mathrm{L}^{-1}$ in DMW3 consisted of $12.6 \mathrm{mg} \mathrm{L}^{-1}$ as $\mathrm{NO}_{3}-\mathrm{N}$ and $37.4 \mathrm{mg} \mathrm{L}^{-1}$ as $\mathrm{NO}_{2}-\mathrm{N}^{\mathrm{b}} \mathrm{NO}_{x}-\mathrm{N}$ max in groundwater was measured in core $\left(\mathrm{NO}_{3}-\mathrm{N}=66.4 \mathrm{mg} \mathrm{L}^{-1}, \mathrm{NO}_{x}-\mathrm{N}=67.8 \mathrm{mg} \mathrm{L}^{-1}\right)$. ${ }^{\mathrm{c}}$ Range across three replicates was measured on 25 August 2011.

DMW3). Pore water extracted from the unsaturated zone (sand) at the top of this core profile contained $865 \mathrm{~m} \mathrm{~L}^{-1}$ of $\mathrm{NO}_{3}-\mathrm{N}$ and had a $\mathrm{NO}_{3}-\mathrm{N} / \mathrm{Cl}^{-}$ratio of 1.04 , consistent with the ratio of 0.95 in the core sample. Given this consistency, and that $\mathrm{NO}_{3}-\mathrm{N}$ concentrations in the well immediately up-gradient were low (DMW3), the $\mathrm{NO}_{3}-\mathrm{N}$ in this core sample was most likely introduced into the groundwater system by vertical infiltration or diffusion from above. In contrast, elevated $\mathrm{NO}_{3}-\mathrm{N}$ (up to $21.1 \mathrm{mg} \mathrm{L}^{-1}$ ) within the sand between 6 and $12 \mathrm{~m}$ depth in this core had $\mathrm{NO}_{3}-\mathrm{N} / \mathrm{Cl}^{-}$ratios consistent with an EMS source (0.07 to 0.31 ). Stable isotope values in pore water from this sand layer do not indicate substantial denitrification $\left(\delta^{18} \mathrm{O} \leq 5.9 \%\right.$, $\delta^{15} \mathrm{~N} \leq 16.7 \%$ ), suggesting these ratios will be similar to the initial ratios at the point of entry to the groundwater system.

In DMW13 (33 m down-gradient from DP10-2) the ratio of $\mathrm{NO}_{3}-\mathrm{N}_{\mathrm{i}} / \mathrm{Cl}_{\mathrm{i}}$ was $0.75 \pm 0.29$, similar to the $\mathrm{NO}_{3}-\mathrm{N} / \mathrm{Cl}^{-}$ ratio in DC15-23 at $2 \mathrm{~m}(0.95)$, which is interpreted as reflecting a top-down source. The $\mathrm{NO}_{3}^{-}$in DMW13 is therefore unlikely to be sourced solely from leakage from the EMS, and could be sourced from the adjacent dairy pens or a temporary manure pile that was observed adjacent to this well during core collection in 2015 (or a combination of EMS and top-down sources).

In DMW12 the $\mathrm{NO}_{3}-\mathrm{N}_{\mathrm{i}} / \mathrm{Cl}_{\mathrm{i}}$ ratio was not inconsistent with an EMS source, but the hydraulic gradient between DMW2 and DMW12 is negligible, indicating a lack of driving force for advective transport from the EMS towards DMW12. This is also the case for well DMW1, which is up-gradient of the EMS but had elevated $\mathrm{NO}_{3}-\mathrm{N}$ concentrations $(6.5 \pm 3.6, n=18)$. The source of nitrate in these wells is therefore unlikely to be related to leakage from the EMS, but alternative sources (i.e. nearby temporary manure piles) are not known.

Well DMW11, $470 \mathrm{~m}$ from the EMS, had consistently low $\mathrm{NO}_{3}-\mathrm{N} / \mathrm{Cl}^{-}$ratios $(<0.05)$, similar to DP10-2, but estimates of $\mathrm{Cl}_{\mathrm{i}}$ were 3 times higher than $\mathrm{Cl}_{\mathrm{i}}$ for DP10-2 (Fig. 4b). $\mathrm{NO}_{3}-\mathrm{N}_{\mathrm{i}}$ and $\mathrm{Cl}_{\mathrm{i}}$ estimated for DMW11 were con- sistent with measured values in that well, indicating a local top-down source. Well DMW11 is located hydraulically down-gradient of feedlot pens and adjacent to a solid manure storage area, in a local topographic low. Elevated $\mathrm{NO}_{3}-\mathrm{N}$ in this well is therefore interpreted to be from surface runoff and top-down infiltration, rather than lateral advection from the EMS.

\subsubsection{CFO4}

At $\mathrm{CFO} 4$, measured data indicate that effects from agricultural operations on $\mathrm{NO}_{3}^{-}$concentrations in groundwater are restricted to the upper $15 \mathrm{~m}$ of the subsurface. $\mathrm{NO}_{3}-\mathrm{N}$ concentrations in wells screened at $15 \mathrm{~m}$ depth were $<$ $0.5 \mathrm{mg} \mathrm{L}^{-1}$, with the exception of one sample from BP10$15 \mathrm{w}$ (May 2012) with $4.3 \mathrm{mg} \mathrm{L}^{-1}$ of $\mathrm{NO}_{3}-\mathrm{N}$. Water table wells in the west and north of the study site (BC1, BC2, and $\mathrm{BC} 3)$ also indicate negligible impacts of agricultural operations, with $\mathrm{Cl}^{-}<10 \mathrm{mg} \mathrm{L}^{-1}$ and $\mathrm{NO}_{3}-\mathrm{N}<0.1 \mathrm{mg} \mathrm{L}^{-1}$.

Concentrations of $\mathrm{NO}_{3}-\mathrm{N}>10 \mathrm{mg} \mathrm{L}^{-1}$ were measured in three water table wells (BMW2, BMW3, BMW4) adjacent to the EMS, indicating that they have been impacted by the EMS (Fig. 5). Of these, BMW2 had much higher $\mathrm{Cl}^{-}$concentrations $\left(502 \pm 97 \mathrm{mg} \mathrm{L}^{-1}, n=22\right.$ in BMW2 compared to $182 \pm 81 \mathrm{mg} \mathrm{L}^{-1}$ in BMW3 and $188 \pm 74 \mathrm{mg} \mathrm{L}^{-1}$ in BMW4), and therefore lower $\mathrm{NO}_{3}-\mathrm{N} / \mathrm{Cl}^{-}$ratios $(<0.05)$. $\mathrm{Cl}^{-}$concentrations in BMW2 were consistent with concentrations in the EMS suggesting direct leakage, while stable isotopes of $\mathrm{NO}_{3}^{-}$and initial concentrations $\left(\mathrm{NO}_{3}-\mathrm{N}_{\mathrm{i}} \geq 127 \mathrm{mg} \mathrm{L}^{-1}\right)$ indicate substantial denitrification (Table 3, Fig. 6). The $\mathrm{NO}_{3}-\mathrm{N}_{\mathrm{i}} / \mathrm{Cl}_{\mathrm{i}}$ ratio in BMW2 is consistent with measured $\mathrm{NO}_{3}-\mathrm{N} / \mathrm{Cl}^{-}$in BMW4, which therefore likely reflects leakage from the EMS without denitrification (consistent with stable isotope of values of $\mathrm{NO}_{3}^{-}$).

Given that the estimated subsurface travel distance during operations at this site is $10 \mathrm{~m}$, agriculturally derived $\mathrm{NO}_{3}^{-}$in other wells not immediately adjacent to the EMS is unlikely to be related to leakage from the EMS. Wells BMW5 and BMW7 are 60 and $140 \mathrm{~m}$ hydraulically down-gradient from 

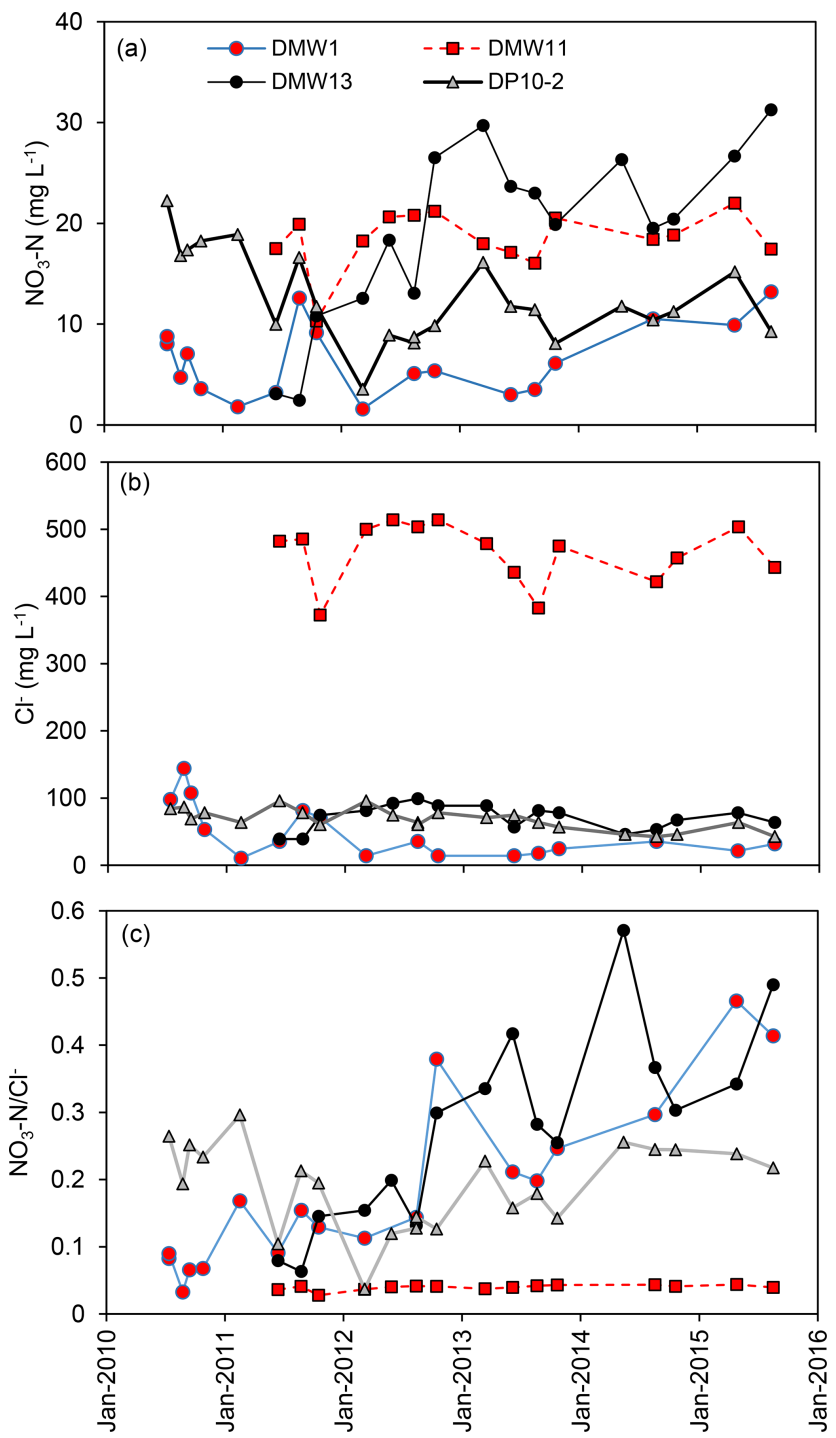

Figure 3. Temporal variations in (a) $\mathrm{NO}_{3}-\mathrm{N}$, (b) $\mathrm{Cl}^{-}$, and (c) $\mathrm{NO}_{3}-\mathrm{N} / \mathrm{Cl}^{-}$at CFO1. Only wells with $\mathrm{NO}_{3}-\mathrm{N}>10 \mathrm{mg} \mathrm{L}{ }^{-1}$ are shown.

the EMS, respectively. $\mathrm{NO}_{3}-\mathrm{N}_{\mathrm{i}} / \mathrm{Cl}_{\mathrm{i}}$ ratios in these wells were not inconsistent with BMW2 (i.e. the range of values overlap), but given the distance from the EMS the source of $\mathrm{NO}_{3}-\mathrm{N}$ in these wells is most likely the adjacent dairy pens. Concentrations of $\mathrm{NO}_{3}-\mathrm{N}>10 \mathrm{mg} \mathrm{L}^{-1}$ were also measured in $\mathrm{BC} 4$, which is located $95 \mathrm{~m}$ hydraulically up-gradient of the EMS. The ratio of $\mathrm{NO}_{3}-\mathrm{N}_{\mathrm{i}} / \mathrm{Cl}_{\mathrm{i}}$ at $\mathrm{BC} 4$ was the highest at CFO4 (0.6) and did not overlap with BMW2. The $\mathrm{NO}_{3}^{-}$in this well is interpreted to have been sourced from an adjacent manure pile, which was observed during the study.
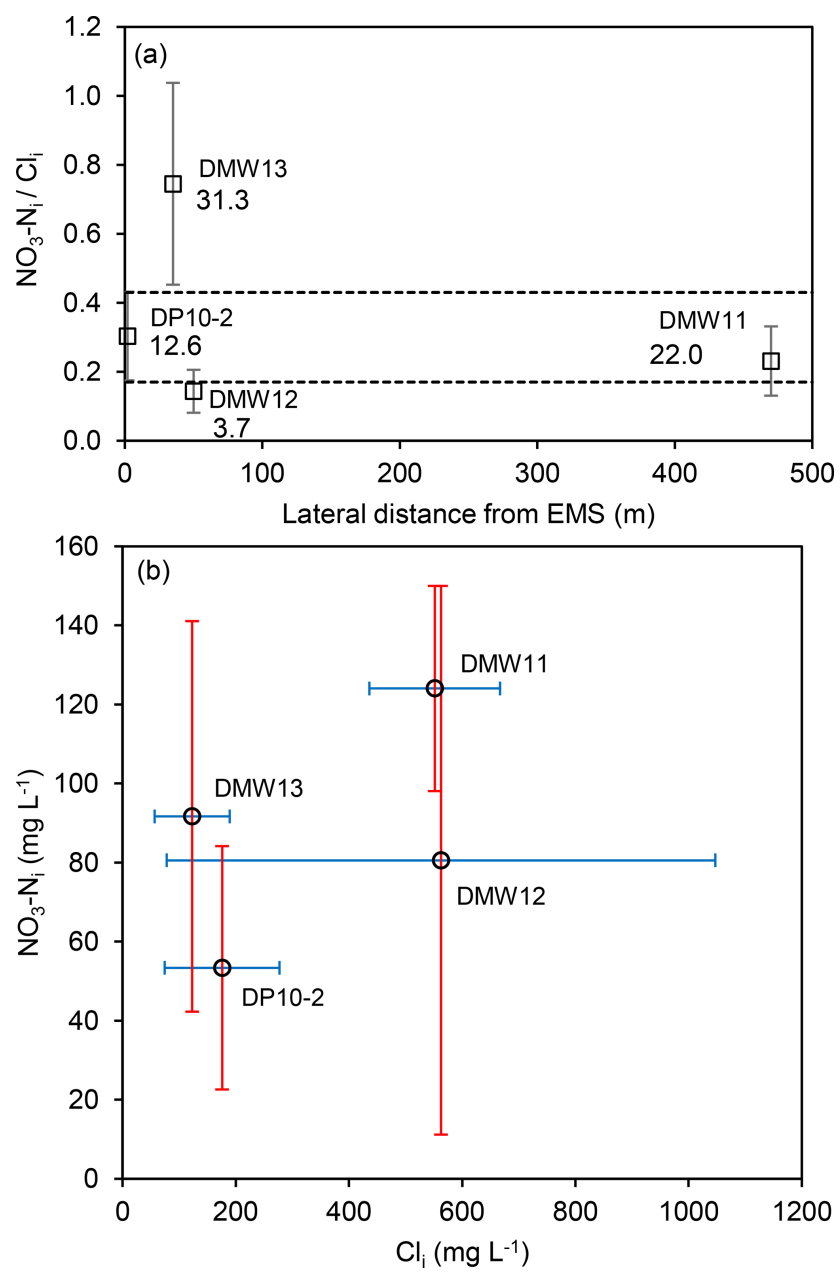

Figure 4. (a) Estimated $\mathrm{NO}_{3}-\mathrm{N}_{i} / \mathrm{Cl}_{i}$ ratios (mean and SD) in water table wells with evidence of denitrification at CFO1, plotted with distance from earthen manure storage (EMS), where dashed lines are the upper and lower bounds of DP10-2 (EMS source) and labelled values are maximum measured $\mathrm{NO}_{3}-\mathrm{N}\left(\mathrm{mg} \mathrm{L}^{-1}\right)$. (b) Estimated concentrations of $\mathrm{NO}_{3}-\mathrm{N}_{i}$ and $\mathrm{Cl}_{i}$ at CFO1 (mid-range, error bars are max and min values).

\subsection{Mechanisms of attenuation of agriculturally derived $\mathrm{NO}_{3}^{-}$}

Attenuation of agriculturally derived $\mathrm{NO}_{3}^{-}$in groundwater is dominated by denitrification at both $\mathrm{CFO} 1$ and $\mathrm{CFO} 4$, with estimates of $f_{\mathrm{m}}$ consistently higher than estimates of $f_{\mathrm{d}}$ (Tables 3 and S10, Fig. 7). Calculated $f_{\mathrm{d}}$ values indicate that where denitrification was identified, at least half of the $\mathrm{NO}_{3}-\mathrm{N}$ present at the initial point of entry to the groundwater system has been removed by this attenuation mechanism. Comparison of $\mathrm{NO}_{3}-\mathrm{N}_{\text {mix }}$ (the concentration of $\mathrm{NO}_{3}-\mathrm{N}$ that would be measured if mixing was the only attenuation mechanism) with measured concentrations (which reflect attenuation by both mixing and denitrification) suggests that the sample from $20 \mathrm{~m}$ depth (DP11-12b) is the only sample 

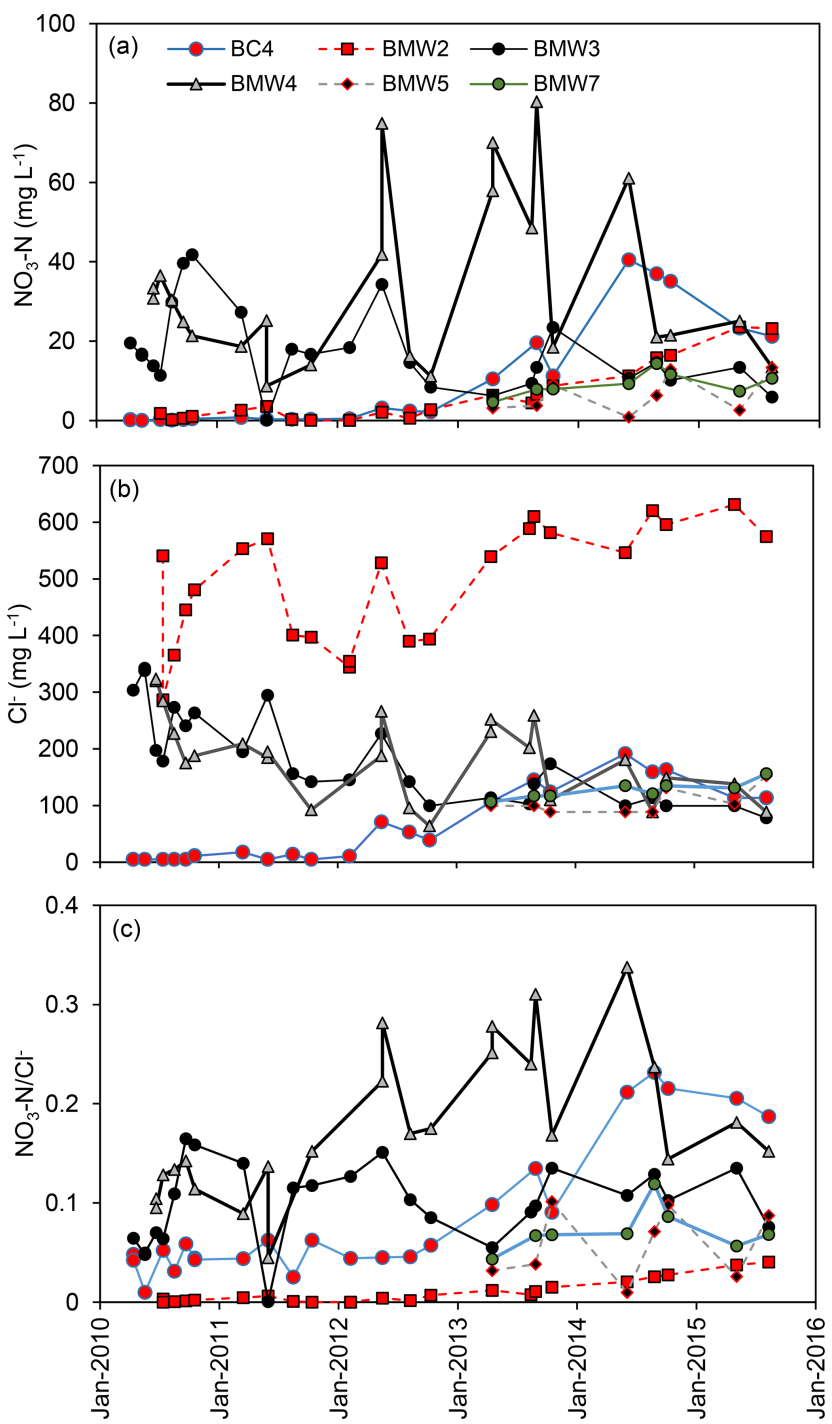

Figure 5. Temporal variations in (a) $\mathrm{NO}_{3}-\mathrm{N}$, (b) $\mathrm{Cl}^{-}$, and (c) $\mathrm{NO}_{3}-\mathrm{N} / \mathrm{Cl}^{-}$at CFO4. Only wells with $\mathrm{NO}_{3}-\mathrm{N}>10 \mathrm{mg} \mathrm{L}^{-1}$ are shown.

that would be below the drinking water guideline if mixing was the only attenuation mechanism (Fig. 8).

At both sites, the stable isotope values of $\mathrm{NO}_{3}^{-}$indicate that denitrification proceeds within metres of the source. At CFO1, calculated $f_{\mathrm{d}}$ in well DP10-2 (2 $\mathrm{m}$ from the EMS) is $0.52 \pm 0.22$; at CFO4, $f_{\mathrm{d}}$ in well BMW2 (3 $\mathrm{m}$ from the EMS) is $0.13 \pm 0.06$. Denitrification also substantially attenuated $\mathrm{NO}_{3}-\mathrm{N}$ concentrations in wells where the source is not the EMS but instead is adjacent solid manure piles (e.g. DMW11 at $\mathrm{CFO} 1, \mathrm{BC} 4$ at $\mathrm{CFO} 4)$. In BMW6 at CFO4, denitrification completely attenuated the agriculturally derived $\mathrm{NO}_{3}^{-}$. This well had negligible $\mathrm{NO}_{3}-\mathrm{N}\left(0.4 \pm 0.2 \mathrm{mg} \mathrm{L}^{-1}, n=8\right)$ and the lowest $f_{\mathrm{d}}$ of 0.01 . Measured DOC in this well was consistent with other wells at both sites $\left(6.9 \pm 1.7 \mathrm{mg} \mathrm{L}^{-1}, n=3\right)$,
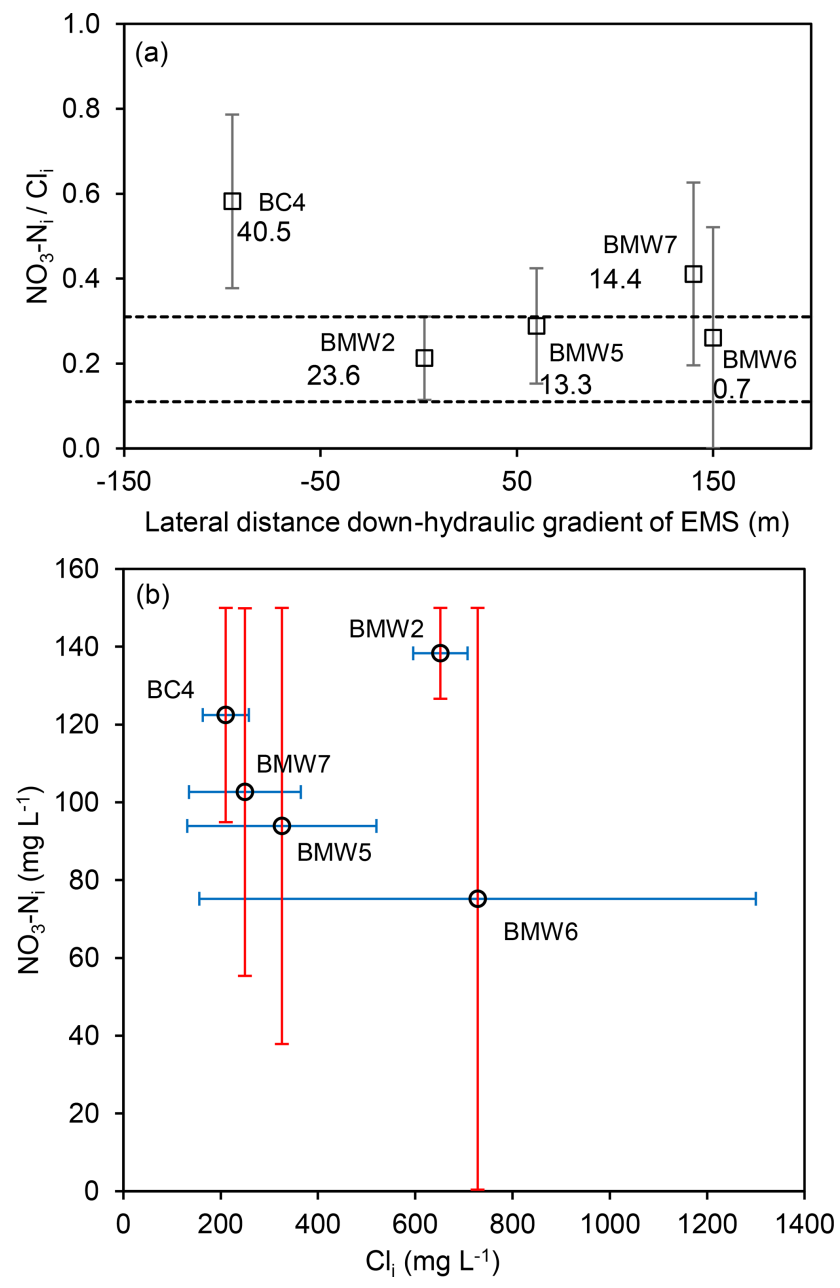

Figure 6. (a) Estimated $\mathrm{NO}_{3}-\mathrm{N}_{i} / \mathrm{Cl}_{i}$ ratios (mean and SD) in water table wells with evidence of denitrification at $\mathrm{CFO} 4$, plotted with distance from earthen manure storage (EMS), where dashed lines are upper and lower bounds of BMW2 (EMS source) and values are maximum measured $\mathrm{NO}_{3}-\mathrm{N}\left(\mathrm{mg} \mathrm{L}^{-1}\right)$. (b) Estimated concentrations of $\mathrm{NO}_{3}-\mathrm{N}_{i}$ and $\mathrm{Cl}_{i}$ at $\mathrm{CFO} 4$ (mid-range, error bars are max and min values).

suggesting DOC depletion does not limit denitrification at these CFOs.

\section{Discussion}

\subsection{Implications for on-farm waste management}

Agriculturally derived $\mathrm{NO}_{3}^{-}$at these two sites with varying lithology was generally restricted to depths $<20 \mathrm{~m}$, consistent with previous studies at CFOs (Robertson et al., 1996; Rodvang and Simpkins, 2001; Rodvang et al., 2004; Kohn et al., 2016). Attenuation of agriculturally derived $\mathrm{NO}_{3}^{-}$in groundwater was a spatially varying combination of mixing and denitrification, with denitrification playing a greater role than mixing at both sites. In the samples for which $f_{\mathrm{d}}$ could 
Table 3. Calculated $f_{\mathrm{d}}$ and $f_{\mathrm{m}}$ based on measured $\mathrm{Cl}^{-}$and $\mathrm{NO}_{3}-\mathrm{N}$ concentrations and stable isotope values of $\mathrm{NO}_{3}^{-}$.

\begin{tabular}{|c|c|c|c|c|c|c|c|}
\hline $\begin{array}{l}\text { Study } \\
\text { area }\end{array}$ & Sample ID ${ }^{\mathrm{a}}$ & $\begin{array}{r}\mathrm{Cl}^{-} \\
\left(\mathrm{mg} \mathrm{L}^{-1}\right)\end{array}$ & $\begin{array}{r}\mathrm{NO}_{3}-\mathrm{N} \\
\left(\mathrm{mg} \mathrm{L}^{-1}\right)\end{array}$ & $\begin{array}{c}\delta^{15} \mathrm{~N}_{\mathrm{NO}_{3}} \\
(\% o)\end{array}$ & $\begin{array}{r}\delta^{18} \mathrm{O}_{\mathrm{NO}_{3}} \\
(\% o)\end{array}$ & $\begin{array}{c}f_{\mathrm{d}} \\
(\mathrm{mean} \pm \\
\mathrm{SD})\end{array}$ & $\begin{array}{c}f_{\mathrm{m}}^{\mathrm{b}} \\
\text { (mid- } \\
\text { range) }\end{array}$ \\
\hline \multirow[t]{11}{*}{ CFO1 } & DP11-13_4.3m & 28.5 & 7.0 & 30.3 & 9.8 & $0.30 \pm 0.15$ & 0.58 \\
\hline & DP11-13_5.2m & 25.0 & 7.8 & 31.0 & 10.8 & $0.34 \pm 0.13$ & 0.58 \\
\hline & DP11-13_7m & 72.3 & 12.0 & 31.6 & 10.2 & $0.27 \pm 0.13$ & 0.65 \\
\hline & DP11-13_7.9m & 70.8 & 9.1 & 36.4 & 14.0 & $0.17 \pm 0.09$ & 0.68 \\
\hline & DP11-13_8.8m & 81.7 & 10.9 & 29.6 & 9.9 & $0.32 \pm 0.15$ & 0.63 \\
\hline & DC15-22_10m & 73.0 & 11.0 & 26.1 & 7.4 & $0.47 \pm 0.21$ & 0.63 \\
\hline & DP10-2 & 74.5 & 11.8 & 24.2 & 4.8 & $0.52 \pm 0.22$ & 0.63 \\
\hline & DMW11 & 436.1 & 17.1 & 33.3 & 10.9 & $0.17 \pm 0.07$ & 0.83 \\
\hline & DMW12 & 78.0 & 2.57 & 29.8 & 14.3 & $0.23 \pm 0.10$ & 0.54 \\
\hline & DMW13 & 56.7 & 23.7 & 23.0 & 6.8 & $0.56 \pm 0.22$ & 0.65 \\
\hline & DP11-12b & 95.7 & 0.6 & 35.9 & 17.0 & $0.15 \pm 0.08$ & 0.54 \\
\hline \multirow[t]{5}{*}{ CFO4 } & $\mathrm{BC} 4$ & 163.1 & 35.1 & 30.6 & 1.6 & $0.37 \pm 0.13$ & 0.82 \\
\hline & BMW2 & 595.6 & 16.5 & 41.6 & 8.3 & $0.13 \pm 0.06$ & 0.92 \\
\hline & BMW5 & 131.2 & 12.9 & 28.9 & 6.5 & $0.34 \pm 0.16$ & 0.63 \\
\hline & BMW6 & 156.0 & 0.4 & 70.5 & 22.1 & $0.01 \pm 0.01$ & 0.56 \\
\hline & BMW7 & 134.7 & 11.6 & 34.0 & 5.9 & $0.21 \pm 0.11$ & 0.68 \\
\hline
\end{tabular}

${ }^{\text {a }}$ Central depth of core samples, $x$, indicated as SampleID_xm. ${ }^{\mathrm{b}}$ Maximum $f_{\mathrm{m}}$ is 1 for all samples, which implies no mixing.

be determined, denitrification reduced $\mathrm{NO}_{3}^{-}$concentrations by at least half and, in some cases, back to background concentrations. Given that the range of source isotopic composition was allowed to vary to its maximum justifiable extent, these quantitative estimates of denitrification based on stable isotopes of $\mathrm{NO}_{3}^{-}$are likely to be conservative. Redox conditions within the groundwater system were not able to be determined in this study due to the sampling method used to collect groundwater from wells screened across low- $K$ formations (well bailed dry then sample collected after water level recovery). However, denitrification appears to proceed within metres of the $\mathrm{NO}_{3}^{-}$source, suggesting relatively short subsurface residence times are required and that redox conditions close to the water table are conducive to denitrification reactions (Critchley et al., 2014; Clague et al., 2015).

The substantial role of denitrification within the saturated glacial sediments at these study sites indicates the potential for significant attenuation of agriculturally derived $\mathrm{NO}_{3}^{-}$ by denitrification in similar groundwater systems across the North American interior and Europe (Ernstsen et al., 2015; Zirkle et al., 2016). Denitrification in the unsaturated zone is limited by low water contents and oxic conditions, resulting in substantial stores of $\mathrm{NO}_{3}^{-}$in vadose zones (Turkeltaub et al., 2016; Ascott et al., 2017). $\mathrm{NO}_{3}^{-}$in water that is removed rapidly from the site is also unlikely to be substantially attenuated by denitrification due to oxic conditions and rapid transit times (Ernstsen et al., 2015). Therefore, water management focussed on reducing the effects of $\mathrm{NO}_{3}^{-}$contamination in similar hydrogeological settings to this study should aim to maximise infiltration into the saturated zone where $\mathrm{NO}_{3}^{-}$concentrations can be naturally attenuated, provided that local groundwater is not used for potable water supply.

At both sites there is evidence of elevated $\mathrm{NO}_{3}^{-}$due to leakage from the EMS, but the impact appears to be limited to within metres of the EMS. This suggests that saturation within the clay lining of the EMS has limited the development of extensive secondary porosity that would allow rapid water percolation (Baram et al., 2012). Infiltration of $\mathrm{NO}_{3}^{-}$rich water that has passed through temporary solid manure piles and dairy pens has resulted in groundwater $\mathrm{NO}_{3}-\mathrm{N}$ concentrations as high as those associated with leakage from the EMS (e.g. DMW11, BC4). At CFO4, this is in spite of the presence of clay at the surface, reflecting secondary porosity in the upper part of the profile that has led to hydraulic conductivities comparable to sand. This is consistent with the findings of Showers et al. (2008), who investigated sources of $\mathrm{NO}_{3}^{-}$at an urbanised dairy farm in North Carolina, USA. Construction of EMS facilities in Alberta has been regulated under the Agriculture Operation Practices Act since 2002, which requires them to be lined with clay to minimise leakage (Lorenz et al., 2014). On-farm waste management should increasingly focus on minimising temporary manure piles that are in direct contact with the soil to reduce $\mathrm{NO}_{3}^{-}$contamination associated with dairy farms and feedlots.

\subsection{Critique of this approach and applicability at other sites}

At both sites, leakage from the EMS had $\mathrm{NO}_{3}-\mathrm{N}_{\mathrm{i}} / \mathrm{Cl}_{\mathrm{i}}$ of between 0.1 and 0.4 , but this alone was not diagnostic of 

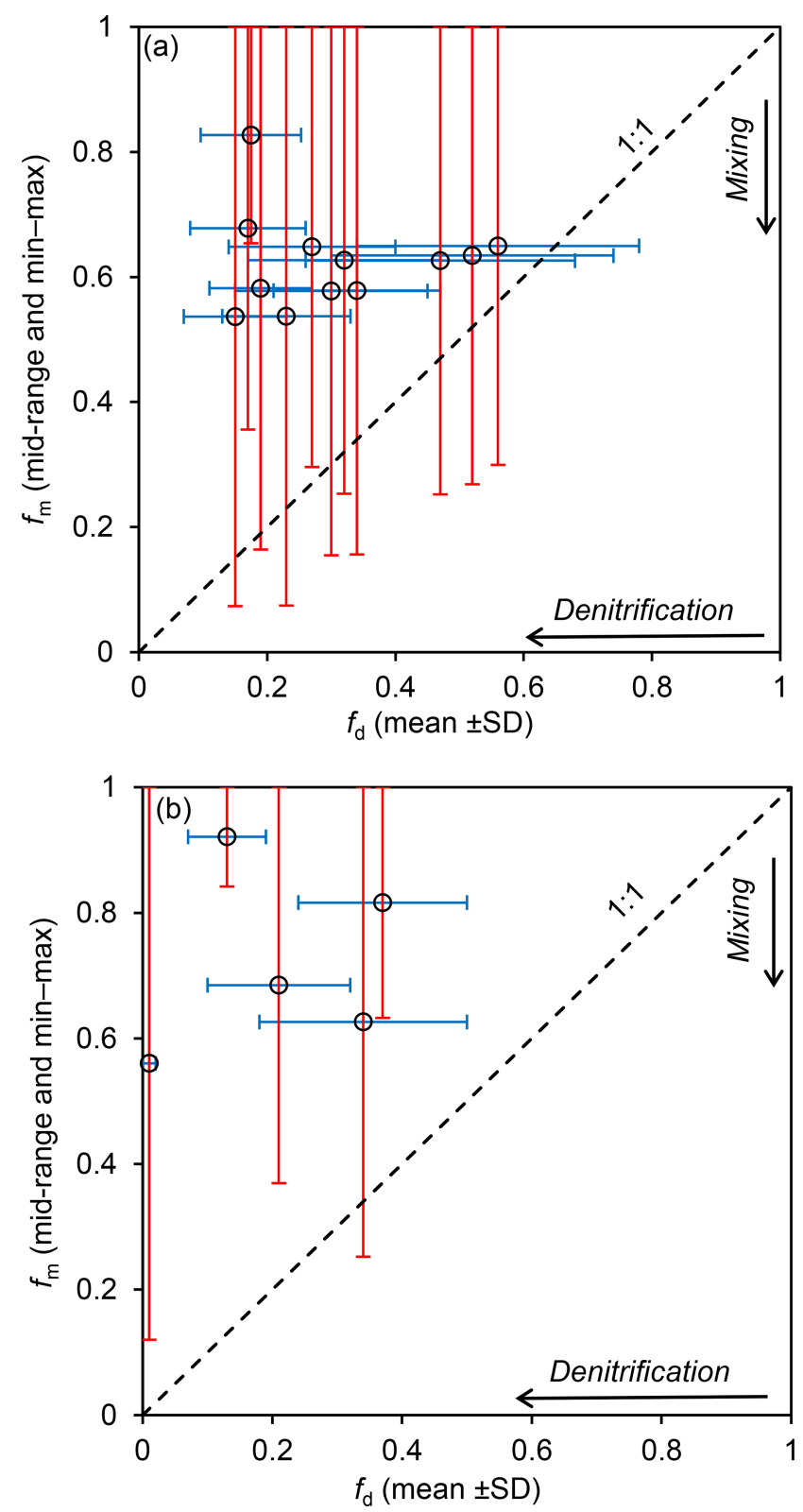

Figure 7. Relative contributions to $\mathrm{NO}_{3}^{-}$attenuation by mixing and denitrification, as indicated by estimated $f_{\mathrm{m}}$ and $f_{\mathrm{d}}$ at (a) CFO1 and (b) $\mathrm{CFO} 4$, for groundwater samples with denitrification indicated by stable isotope values of $\mathrm{NO}_{3}^{-}$.

the source. The sources of manure-derived $\mathrm{NO}_{3}^{-}$(manure piles vs. EMS) are distinguishable based on $\mathrm{NO}_{3}-\mathrm{N}_{\mathrm{i}} / \mathrm{Cl}_{\mathrm{i}}$ ratios, provided there is also an understanding of the history of each site, local hydrogeology, and potential sources. Calculated $f_{\mathrm{d}}$ and $f_{\mathrm{m}}$ generally decreased with increasing subsurface residence time and distance from source, providing additional evidence for source attribution. For example, at CFO4, well BMW2, which is adjacent to the EMS, had the highest $f_{\mathrm{m}}(0.92)$, indicating the least attenuation of $\mathrm{NO}_{3}$ by mixing and consistent with the EMS being the source of
$\mathrm{NO}_{3}^{-}$to this well. Temporal variability in $\mathrm{NO}_{3}-\mathrm{N}_{\mathrm{i}} / \mathrm{Cl}_{\mathrm{i}}$ for each source could not be determined based on the snapshot isotope sampling conducted, but this could be investigated by measuring $\mathrm{NO}_{3}^{-}$isotopes in conjunction with $\mathrm{NO}_{3}-\mathrm{N}$ and $\mathrm{Cl}^{-}$at multiple times.

Calculation of $\mathrm{NO}_{3}-\mathrm{N}_{\mathrm{i}} / \mathrm{Cl}_{\mathrm{i}}$ assumed that background concentrations could be neglected in the mixing model. At these study sites, background concentrations are likely to be $<20 \mathrm{mg} \mathrm{L}^{-1}$ for $\mathrm{Cl}^{-}$and $<1 \mathrm{mg} \mathrm{L}^{-1}$ for $\mathrm{NO}_{3}-\mathrm{N}$. Estimated $\mathrm{NO}_{3}-\mathrm{N}_{\mathrm{i}}$ values were at least 20 times background $\mathrm{NO}_{3}-\mathrm{N}$ concentrations, and over 100 times background concentrations in some wells. The estimated $\mathrm{Cl}_{i}$ values were at least 3 times as high as the background concentrations at $\mathrm{CFO} 1$ and at least 10 times as high as the background concentrations at $\mathrm{CFO} 4$. The error introduced by neglecting background concentrations was assessed by comparing $f_{\mathrm{m}}$ calculated with and without background concentrations included, using the full range of values in this study (Fig. 9). Neglecting background concentrations results in overestimation of $f_{\mathrm{m}}$ (i.e. underestimation of the amount of attenuation mixing) with the largest errors occurring when measured concentrations are close to background concentrations. For $\mathrm{Cl}^{-}$the maximum difference of 0.13 is in the mid-range of $f_{\mathrm{m}}$ values. For $\mathrm{NO}_{3}-\mathrm{N}$, the difference is consistently $<0.1$ with the largest errors at the lowest values of $f_{\mathrm{m}}$. The uncertainty in $f_{\mathrm{m}}$ is primarily related to uncertainty in the initial concentrations $\left(\mathrm{Cl}_{\mathrm{i}}\right.$ and $\left.\mathrm{NO}_{3}-\mathrm{N}_{\mathrm{i}}\right)$, which depends on measured $\mathrm{Cl}^{-}$and $\mathrm{NO}_{3}-\mathrm{N}$. The largest uncertainties in $\mathrm{NO}_{3}-\mathrm{N}_{\mathrm{i}}$ and $\mathrm{Cl}_{\mathrm{i}}$ correspond to the lowest measured concentrations (i.e. furthest from the upper limit), with less uncertainty at higher measured concentrations as they approach the maximum values.

Although applicable at these sites, this approach may not be valid at other sites if additional sources of $\mathrm{NO}_{3}$ in groundwater (e.g. fertiliser or nitrification) are significant, or if $\mathrm{NO}_{3}$ concentrations in groundwater are naturally elevated (Hendry et al., 1984). The combination of the approach outlined here with measurement of groundwater age indicators would allow for better constraints on groundwater flow velocities and determination of denitrification rates (Böhlke and Denver, 1995; Katz et al., 2004; McMahon et al., 2004; Clague et al., 2015).

\subsection{Comparison with isotopic values of $\mathrm{NO}_{3}^{-}$in previous studies}

Nitrate isotope values in groundwater at the two CFOs studied were generally consistent with previous studies reporting denitrification of manure-derived $\mathrm{NO}_{3}^{-}$at dairy farms (Wassenaar, 1995; Wassenaar et al., 2006; Singleton et al., 2007; McCallum et al., 2008; Baily et al., 2011). However, the isotopic values of $\mathrm{NO}_{3}^{-}$in the manure filtrate from the EMS at CFO1 were not consistent with values for manuresourced $\mathrm{NO}_{3}^{-}$reported in other groundwater studies (Wassenaar, 1995; Wassenaar et al., 2006; Singleton et al., 2007; 

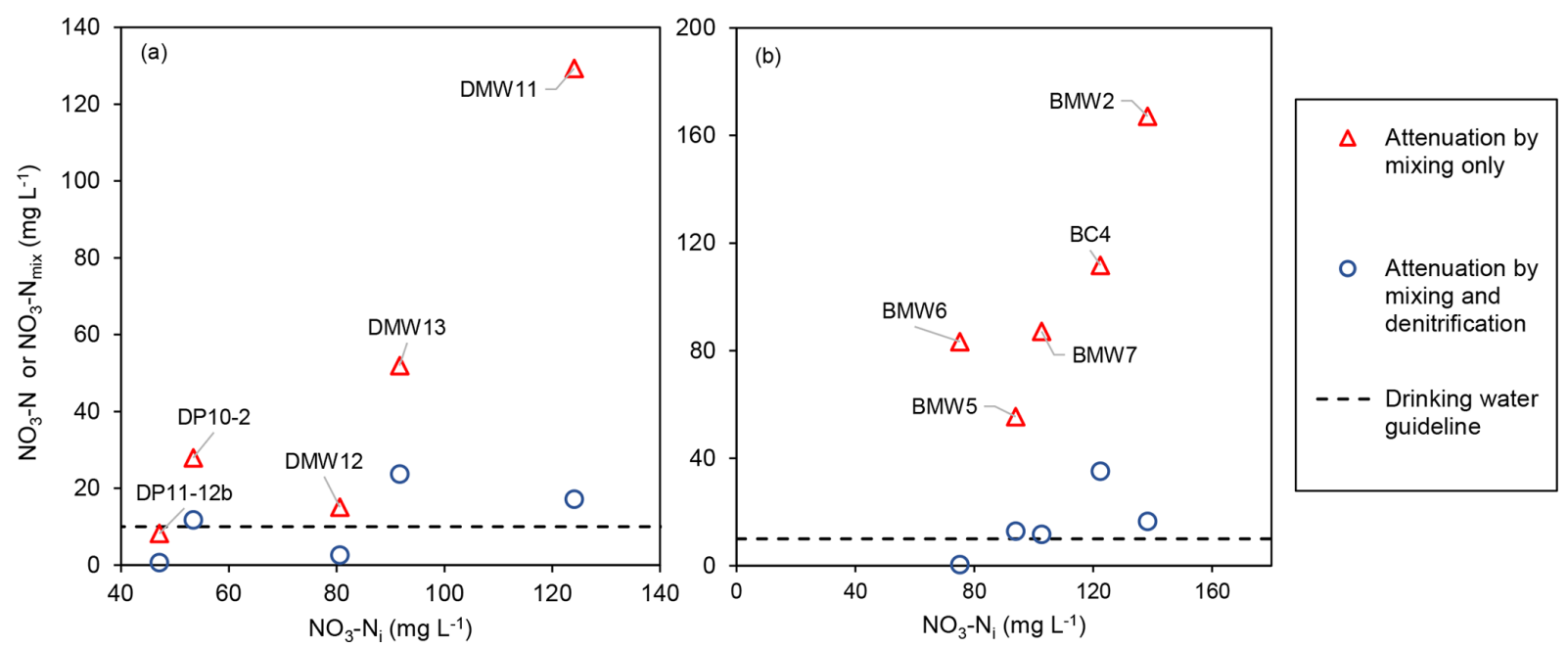

Figure 8. Measured concentrations of $\mathrm{NO}_{3}-\mathrm{N}$ (blue circles - attenuation by mixing and denitrification) and $\mathrm{NO}_{3}-\mathrm{N}_{\text {mix }}(\mathrm{red}$ triangles attenuation by mixing only) vs. mid-range estimate of $\mathrm{NO}_{3}-\mathrm{N}_{i}$ at (a) CFO1 and (b) CFO4. Dashed lines are drinking water guideline $\left(10 \mathrm{mg} \mathrm{L}^{-1}\right.$ of $\left.\mathrm{NO}_{3}-\mathrm{N}\right)$.

McCallum et al., 2008; Baily et al., 2011). This is likely to be because nitrification within the EMS was negligible $\left(\mathrm{NO}_{3}-\mathrm{N}<0.7 \mathrm{mg} \mathrm{L}^{-1}\right)$, such that the isotopic values of $\mathrm{NO}_{3}-\mathrm{N}$ in the manure filtrate reflect volatilisation of $\mathrm{NH}_{3}$ and partial nitrification within the EMS. $\delta^{18} \mathrm{O}_{\mathrm{NO}_{3}}$ values may also have been affected by evaporative enrichment of the $\delta^{18} \mathrm{O}_{\mathrm{H}_{2} \mathrm{O}}$ being incorporated into $\mathrm{NO}_{3}^{-}$(Showers et al., 2008).

A number of groundwater samples collected during this study had relatively enriched $\delta^{18} \mathrm{O}_{\mathrm{NO}_{3}}(>15 \%$ ) with depleted $\delta^{15} \mathrm{~N}_{\mathrm{NO}_{3}}(<15 \%)$. Some of these isotopic values are within the range previously reported for $\mathrm{NO}_{3}^{-}$derived from inorganic fertiliser $\left(\delta^{15} \mathrm{~N}_{\mathrm{NO}_{3}}\right.$ from -3 to $3 \%$ and $\delta^{18} \mathrm{O}_{\mathrm{NO}_{3}}$ from -5 to $25 \%$ o), with the $\delta^{18} \mathrm{O}_{\mathrm{NO}_{3}}$ depending on whether the $\mathrm{NO}_{3}^{-}$is from $\mathrm{NH}_{4}^{+}$or $\mathrm{NO}_{3}^{-}$in the fertiliser (Mengis et al., 2001; Wassenaar et al., 2006; Xue et al., 2009). To the best of our knowledge, however, no inorganic fertilisers have been applied at these study sites. Another potential source is $\mathrm{NO}_{3}^{-}$derived from soil organic $\mathrm{N}$, but this should have $\delta^{15} \mathrm{~N}_{\mathrm{NO}_{3}}$ values of 0 to $10 \%$ and $\delta^{18} \mathrm{O}_{\mathrm{NO}_{3}}$ values of -10 to $15 \%$ (Durka et al., 1994; Mayer et al., 2001; Mengis et al., 2001; Xue et al., 2009; Baily et al., 2011). Incomplete nitrification of $\mathrm{NH}_{4}^{+}$can result in $\delta^{15} \mathrm{~N}_{\mathrm{NO}_{3}}$ lower than the manure source (Choi et al., 2003), but as there was no measurable $\mathrm{NH}_{3}-\mathrm{N}$ in these samples this is also unlikely. These isotope values may reflect the influence of $\mathrm{NO}_{3}^{-}$from precipitation, which usually has values ranging from -5 to $5 \%$ for $\delta^{15} \mathrm{~N}_{\mathrm{NO}_{3}}$ and 40 to $60 \%$ or for $\delta^{18} \mathrm{O}_{\mathrm{NO}_{3}}$ and has been reported to dominate $\mathrm{NO}_{3}^{-}$isotope values of groundwater under forested landscapes (Durka et al., 1994). Alternatively, they may be affected by microbial immobilisation and subsequent mineralisation and nitrification, which can mask the source $\delta^{18} \mathrm{O}_{\mathrm{NO}_{3}}$ in aquifers with long residence times (Mengis et al., 2001; Rivett et al., 2008).

\section{Conclusions}

A mixing model constrained by quantitative estimates of denitrification from isotopes substantially improved our understanding of nitrate contamination at these sites. This novel approach has the potential to be widely applied as a tool for monitoring and assessment of groundwater in complex agricultural settings. $\mathrm{NO}_{3}-\mathrm{N}$ concentrations in excess of the drinking water guideline were measured at both sites, with sources including manure piles, pens, and the EMS. Even though these sites are dominated by clay-rich glacial sediments, the input of $\mathrm{NO}_{3}^{-}$to groundwater from temporary manure piles and pens resulted in $\mathrm{NO}_{3}-\mathrm{N}$ concentrations comparable to (or greater than) leakage from the EMS. This is attributed to the development of secondary porosity within unsaturated clays.

Nitrate attenuation at both sites is dominated by denitrification, which is evident even in wells directly adjacent to the $\mathrm{NO}_{3}^{-}$source. In the wells for which denitrification was identified, concentrations of agriculturally derived $\mathrm{NO}_{3}^{-}$had been reduced by at least half and, in some wells, completely. In the absence of denitrification all but one of these wells would have had $\mathrm{NO}_{3}-\mathrm{N}$ concentrations above the drinking water guideline.

These results indicate that infiltration to groundwater systems in glacial sediments where $\mathrm{NO}_{3}^{-}$can be naturally attenuated is likely to be preferable to off-farm export via runoff or drainage networks, provided that local groundwater is not a potable water source. On-farm management of manure waste at similar operations should increasingly focus on limiting manure piles that are in direct contact with the soil to limit $\mathrm{NO}_{3}^{-}$contamination of groundwater. 

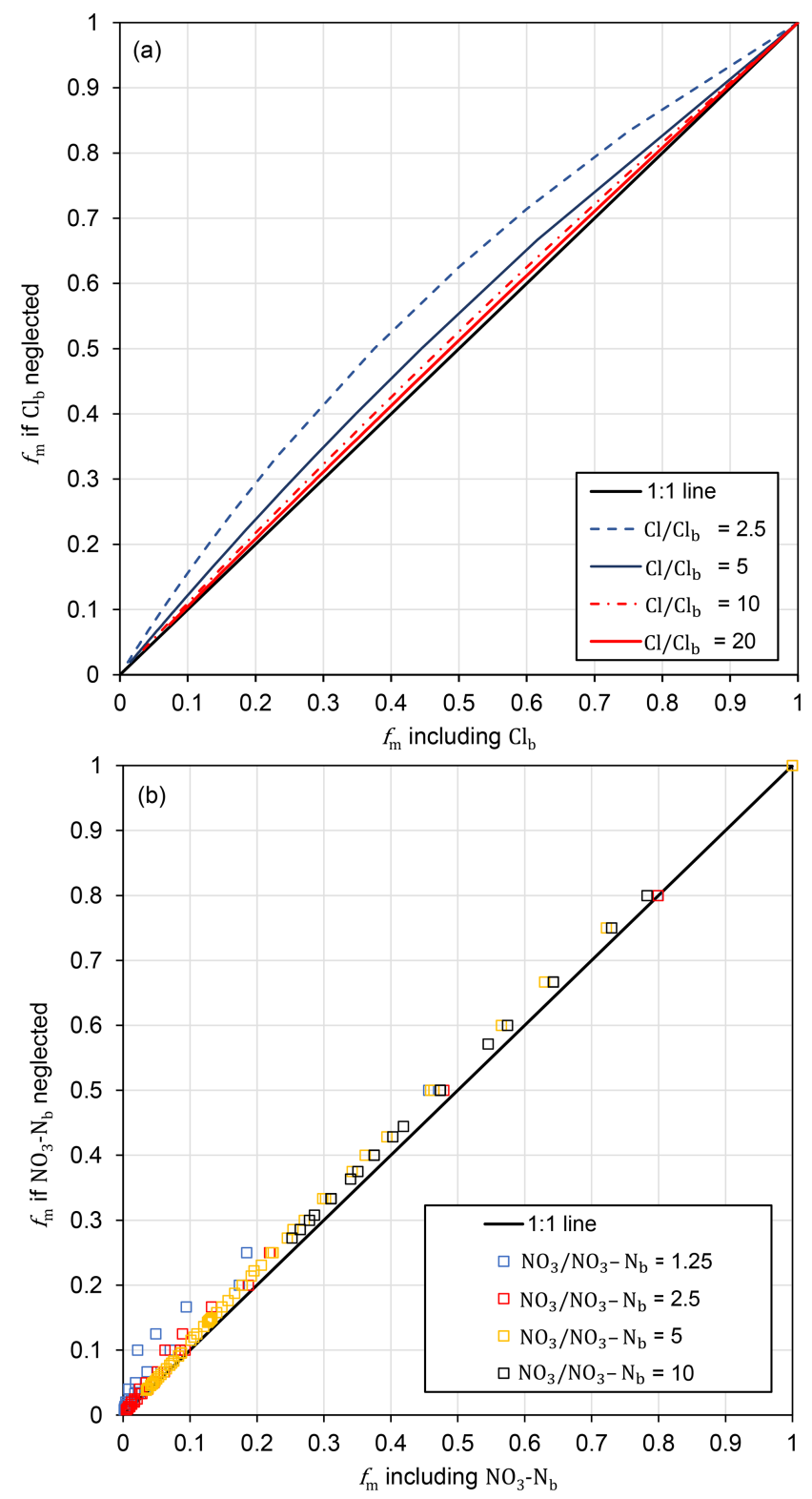

Figure 9. Effect of neglecting background concentrations $\left(\mathrm{Cl}_{\mathrm{b}}\right.$ or $\mathrm{NO}_{3}-\mathrm{N}_{\mathrm{b}}$ ) in the mixing model on calculated $f_{\mathrm{m}}$ over the range of values in this study.

Data availability. Alberta Agriculture and Forestry are the custodians of the data used in this paper.

Supplement. The supplement related to this article is available online at: https://doi.org/10.5194/hess-23-1355-2019-supplement.

Author contributions. Investigation was carried out by SB, MI and JM with assistance from staff at AAF, NRCB and USask. SB developed the data analysis methodology and prepared the paper. All co- authors contributed to supervision, conceptualization, review and editing.

Competing interests. The authors declare that they have no conflict of interest.

Acknowledgements. This research was supported by Alberta Agriculture and Forestry (AAF) and the Natural Resources Conservation Board (NRCB), who provided assistance with field work and laboratory analysis. Funding was also provided by a Natural Sciences and Engineering Research Council of Canada (NSERC) Industrial Research Chair (IRC) (184573) awarded to M. Jim Hendry. The authors thank Barry Olson at AAF for reviewing the paper. Our thanks also to the local producers, whose cooperation made this research possible. And finally, our thanks to Sebastien Lamontagne, Huaiwei Sun and anonymous reviewers for their valuable comments and suggestions during the review process.

Edited by: Bill X. Hu

Reviewed by: Huaiwei Sun and three anonymous referees

\section{References}

Arauzo, M.: Vulnerability of groundwater resources to nitrate pollution: A simple and effective procedure for delimiting $\mathrm{Ni}$ trate Vulnerable Zones, Sci. Total Environ., 575, 799-812, https://doi.org/10.1016/j.scitotenv.2016.09.139, 2017.

Aravena, R., Evans, M., and Cherry, J. A.: Stable isotopes of oxygen and nitrogen in source identification of nitrate from septic systems, Groundwater, 31, 180-186, 1993.

Ascott, M. J., Gooddy, D. C., Wang, L., Stuart, M. E., Lewis, M. A., Ward, R. S., and Binley, A. M.: Global patterns of nitrate storage in the vadose zone, Nat. Commun., 8, 1416, https://doi.org/10.1038/s41467-017-01321-w, 2017.

Baily, A., Rock, L., Watson, C., and Fenton, O.: Spatial and temporal variations in groundwater nitrate at an intensive dairy farm in south-east Ireland: Insights from stable isotope data, Agr. Ecosyst. Environ., 144, 308-318, 2011.

Baram, S., Kurtzman, D., and Dahan, O.: Water percolation through a clayey vadose zone, J. Hydrol., 424-425, 165-171, https://doi.org/10.1016/j.jhydrol.2011.12.040, 2012.

Böhlke, J. K. and Denver, J. M.: Combined use of groundwater dating, chemical, and isotopic analyses to resolve the history and fate of nitrate contamination in two agricultural watersheds, Atlantic Coastal Plain, Maryland, Water Resour. Res., 31, 2319 2339, https://doi.org/10.1029/95WR01584, 1995.

Böttcher, J., Strebel, O., Voerkelius, S., and Schmidt, H. L.: Using isotope fractionation of nitrate-nitrogen and nitrateoxygen for evaluation of microbial denitrification in a sandy aquifer, J. Hydrol., 114, 413-424, https://doi.org/10.1016/00221694(90)90068-9, 1990.

Bourke, S. A., Cook, P. G., Dogramaci, S., and Kipfer, R.: Partitioning sources of recharge in environments with groundwater recirculation using carbon-14 and CFC-12, J. Hydrol., 525, 418-428, 2015a. 
Bourke, S. A., Turchenek, J., Schmeling, E. E., Mahmood, F. N., Olson, B. M., and Hendry, M. J.: Comparison of continuous core profiles and monitoring wells for assessing groundwater contamination by agricultural nitrate, Ground Water Monit. Remediat., 35, 110-117, 2015b.

Choi, W.-J., Lee, S.-M., and Ro, H.-M.: Evaluation of contamination sources of groundwater $\mathrm{NO}_{3}^{-}$using nitrogen isotope data: $\mathrm{A}$ review, Geosci. J., 7, 81-87, 2003.

Clague, J. C., Stenger, R., and Clough, T. J.: Evaluation of the stable isotope signatures of nitrate to detect denitrification in a shallow groundwater system in New Zealand, Agr. Ecosyst. Environ., 202, 188-197, https://doi.org/10.1016/j.agee.2015.01.011, 2015.

Clark, I. D. and Fritz, P.: Environmental Isotopes in Hydrogeology, CRC Press, Boca Raton, Florida, 1997.

Critchley, K., Rudolph, D., Devlin, J., and Schillig, P.: Stimulating in situ denitrification in an aerobic, highly permeable municipal drinking water aquifer, J. Contam. Hydrol., 171, 66-80, 2014.

Deutsch, B., Mewes, M., Liskow, I., and Voss, M.: Quantification of diffuse nitrate inputs into a small river system using stable isotopes of oxygen and nitrogen in nitrate, Org. Geochem., 37, 1333-1342, https://doi.org/10.1016/j.orggeochem.2006.04.012, 2006.

Dogramaci, S., Skrzypek, G., Dodson, W., and Grierson, P. F.: Stable isotope and hydrochemical evolution of groundwater in the semi-arid Hamersley Basin of subtropical northwest Australia, J. Hydrol., 475, 281-293, https://doi.org/10.1016/j.jhydrol.2012.10.004, 2012.

Durka, W., Schulze, E.-D., Gebauer, G., and Voerkeliust, S.: Effects of forest decline on uptake and leaching of deposited nitrate determined from ${ }^{15} \mathrm{~N}$ and ${ }^{18} \mathrm{O}$ measurements, Nature, 372, 765767,1994

Ernstsen, V., Olsen, P., and Rosenbom, A. E.: Long-term monitoring of nitrate transport to drainage from three agricultural clayey till fields, Hydrol. Earth Syst. Sci., 19, 3475-3488, https://doi.org/10.5194/hess-19-3475-2015, 2015.

Fan, A. M. and Steinberg, V. E.: Health implications of nitrate and nitrite in drinking water: An update on methemoglobinemia occurrence and reproductive and developmental toxicity, Regul. Toxicol. Pharmacol., 23, 35-43, https://doi.org/10.1006/rtph.1996.0006, 1996.

Fukada, T., Kisock, K. M., Dennis, P. F., and Grischek, T.: A dual isotope approach to identify denitrification in groundwater at a river-bank infiltration site, Water Res., 37, 3070-3078, 2003.

Galloway, J. N., Townsend, A. R., Erisman, J. W., Bekunda, M., Cai, Z., Freney, J. R., Martinelli, L. A., Seitzinger, S. P., and Sutton, M. A.: Transformation of the nitrogen cycle: Recent trends, questions, and potential solutions, Science, 320, 889-892, https://doi.org/10.1126/science.1136674, 2008.

Granger, J., Sigman, D. M., Lehmann, M. F., and Tortell, P. D.: Nitrogen and oxygen isotope fractionation during dissimilatory nitrate reduction by denitrifying bacteria, Limnol. Oceanogr., 53, 2533-2545, https://doi.org/10.4319/lo.2008.53.6.2533, 2008.

Green, C. T., Böhlke, J. K., Bekins, B. A., and Phillips, S. P.: Mixing effects on apparent reaction rates and isotope fractionation during denitrification in a heterogeneous aquifer, Water Resour. Res., 46, W08525, https://doi.org/10.1029/2009WR008903, 2010.

Gulis, G., Czompolyova, M., and Cerhan, J. R.: An ecologic study of nitrate in municipal drinking water and cancer inci- dence in Trnava District, Slovakia, Environ. Res., 88, 182-187, https://doi.org/10.1006/enrs.2002.4331, 2002.

Hautman, D. P. and Munch, D. J.: Method 300.1 Determination of inorganic anions in drinking water by ion chromatography, US Environmental Protection Agency, Cincinnati, OH, 1997.

Hendry, M. J., McCready, R. G., and Gould, W. D.: Distribution and evolution of nitrate in a glacial till of sourther Alberta, Canada, J. Hydrol., 70, 177-198, 1984.

Hendry, M. J., Barbour, S. L., Novakowski, K., and Wassenaar, L. I.: Paleohydrogeology of the Cretaceous sediments of the Williston Basin using stable isotopes of water, Water Resour. Res., 49, 4580-4592, 2013.

Hvorslev, M. J.: Time Lag and Soil Permeability in Ground-Water Observations, Bull. No. 36, Waterways Exper. Sta. Corps of Engrs, US Army, Vicksburg, Mississippi, 1-50, 1951.

Ji, X., Runtin, X., Hao, Y., and Lu, J.: Quantitative identification of nitrate pollution sources and uncertainty analysis based on dual isotope approach in an agricultural watershed, Environ. Poll., 229, 586-594, 2017.

Joerin, C., Beven, K. J., Iorgulescu, I., and Musy, A.: Uncertainty in hydrograph separations based on geochemical mixing models, J. Hydrol., 255, 90-106, 2002.

Katz, B. G., Chelette, A. R., and Pratt, T. R.: Use of chemical and isotopic tracers to assess nitrate contamination and groundwater age, Woodville Karst Plain, USA, J. Hydrol., 289, 36-61, https://doi.org/10.1016/j.jhydrol.2003.11.001, 2004.

Kaushal, S. S., Groffman, P. M., Band, L. E., Elliott, E. M., Shields, C. A., and Kendall, C.: Tracking nonpoint source nitrogen pollution in human-impacted watersheds, Environ. Sci. Technol., 45, 8225-8232, https://doi.org/10.1021/es200779e, 2011.

Kendall, C. and Aravena, R.: Nitrate isotopes in groundwater systems, in: Environmental Tracers in Subsurface Hydrology, edited by: Cook, P. and Herczeg, A., Springer US, Boston, MA, 261297, 2000.

Kimble, J. M., Bartlett, R. J., McIntosh, J. L., and Varney, K. E.: Fate of nitrate from manure and inorganic nitrogen in a clay soil cropped to continuous corn, J. Environ. Qual., 1, 413415, https://doi.org/10.2134/jeq1972.00472425000100040017x, 1972.

Kohn, J., Soto, D. X., Iwanyshyn, M., Olson, B., Kalischuk, A., Lorenz, K., and Hendry, M. J.: Groundwater nitrate and chloride trends in an agriculture-intensive area in southern Alberta, Canada, Water Qual. Res. J., 51, 47-59, https://doi.org/10.2166/wqrjc.2015.132, 2016.

Komor, S. C. and Anderson, H. W.: Nitrogen isotopes as indicators of nitrate sources in Minnesota sand-plain aquifers, Ground Water, 31, 260-270, 1993.

Lentz, R. D. and Lehrsch, G. A.: Temporal changes in $\delta^{15} \mathrm{~N}^{-}$and $\delta^{18} \mathrm{O}$ of nitrate nitrogen and $\mathrm{H}_{2} \mathrm{O}$ in shallow groundwater: Transit time and nitrate-source implications for an irrigated tract in southern Idaho, Agric. Water Manage., 212, 126-135, 2019.

Liu, C.-Q., Li, S.-L., Lang, Y.-C., and Xiao, H.-Y.: Using $\delta^{15} \mathrm{~N}-$ and $\delta^{18} \mathrm{O}$-values to identify nitrate sources in karst ground water, Guiyang, Southwest China, Environ. Sci. Technol., 40, 69286933, 2006.

Lorenz, K., Iwanyshyn, M., Olson, B., Kalischuk, A., and Pentland, J. (Eds.): Livestock Manure Impacts on Groundwater Quality in Alberta Project 2008 to 2015: 2008 to 2011 Progress Report, Al- 
berta Agriculture and Rural Development, Lethbridge, Alberta, Canada, 316 pp., 2014.

Mariotti, A., Landreau, A., and Simon, B.: ${ }^{15} \mathrm{~N}$ isotope biogeochemistry and natural denitrification process in groundwater: Application to the chalk aquifer of northern France, Geochim. Cosmochim. Ac., 52, 1869-1878, 1988.

Mayer, B., Bollwerk, S. M., Mansfeldt, T., Hütter, B., and Veizer, J.: The oxygen isotope composition of nitrate generated by nitrification in acid forest floors, Geochim. Cosmochim. Ac., 65, 2743-2756, 2001.

McCallum, J. E., Ryan, M. C., Mayer, B., and Rodvang, S. J.: Mixing-induced groundwater denitrification beneath a manured field in southern Alberta, Canada, Appl. Geochem., 23, 21462155, 2008.

McMahon, P. B., Böhlke, J. K., and Christenson, S. C.: Geochemistry, radiocarbon ages, and paleorecharge conditions along a transect in the central High Plains aquifer, southwestern Kansas, USA, Appl. Geochem., 19, 1655-1686, 2004.

Menció, A., Mas-Pla, J., Otero, N., Regàs, O., Boy-Roura, M., Puig, R., Bach, J., Domènech, C., Zamorano, M., Brusi, D., and Folch, A.: Nitrate pollution of groundwater; all right..., but nothing else?, Sci. Total Environ., 539, 241-251, 2016.

Mengis, M., Schif, S. L., Harris, M., English, M. C., Aravena, R., Elgood, R. J., and MacLean, A.: Multiple geochemical and isotopic approaches for assessing ground water $\mathrm{NO}^{3-}$ elimination in a riparian zone, Ground Water, 37, 448-457, 1999.

Mengis, M., Walther, U., Bernasconi, S. M., and Wehrli, B.: Limitations of using $\delta^{18} \mathrm{O}$ for the source identification of nitrate in agricultural soils, Environ. Sci. Technol., 35, 1840-1844, 2001.

Otero, N., Torrentó, C., Soler, A., Menció, A., and Mas-Pla, J.: Monitoring groundwater nitrate attenuation in a regional system coupling hydrogeology with multi-isotopic methods: The case of Plana de Vic (Osona, Spain), Agr. Ecosyst. Environ., 133, 103113, 2009.

Pastén-Zapata, E., Ledesma-Ruiz, R., Harter, T., Ramírez, A. I., and Mahlknecht, J.: Assessment of sources and fate of nitrate in shallow groundwater of an agricultural area by using a multi-tracer approach, Sci. Total Environ., 470-471, 855-864, 2014.

Pauwels, H., Foucher, J.-C., and Kloppmann, W.: Denitrification and mixing in a schist aquifer: Influence on water chemistry and isotopes, Chem. Geol., 168, 307-324, 2000.

Power, J. F. and Schepers, J. S.: Nitrate contamination of groundwater in North America, Agr. Ecosyst. Environ., 26, 165-187, 1989.

Rivett, M. O., Buss, S. R., Morgan, P., Smith, J. W., and Bemment, C. D.: Nitrate attenuation in groundwater: A review of biogeochemical controlling processes, Water Res., 42, 4215-4232, 2008.

Robertson, W., Russell, B., and Cherry, J.: Attenuation of nitrate in aquitard sediments of southern Ontario, J. Hydrol., 180, 267281, 1996.

Rodvang, S. and Simpkins, W.: Agricultural contaminants in Quaternary aquitards: A review of occurrence and fate in North America, Hydrogeol. J., 9, 44-59, 2001.

Rodvang, S. , Schmidt-Bellach, R., and Wassenaar, L. : Nitrate in groundwater below irrigated fields, Alberta Agriculture, Food and Rural Development, Alberta, 1998.
Rodvang, S., Mikalson, D., and Ryan, M.: Changes in ground water quality in an irrigated area of southern Alberta, J. Environ. Qual., 33, 476-487, 2004.

Saffigna, P. G. and Keeney, D. R.: Nitrate and chloride in ground water under irrigated agriculture in central Wisconsin, Ground Water, 15, 170-177, 1977.

Showers, W. J., Genna, B., McDade, T., Bolich, R., and Fountain, J. C.: Nitrate contamination in groundwater on an urbanized dairy farm, Environ. Sci. Technol., 42, 4683-4688, https://doi.org/10.1021/es071551t, 2008.

Sigman, D. M., Casciotti, K. L., Andreani, M., Barford, C., Galanter, M., and Böhlke, J. K.: A bacterial method for the nitrogen isotopic analysis of nitrate in seawater and freshwater, Anal. Chem., 73, 4145-4153, https://doi.org/10.1021/ac010088e, 2001.

Singleton, M., Esser, B., Moran, J., Hudson, G., McNab, W., and Harter, T.: Saturated zone denitrification: Potential for natural attenuation of nitrate contamination in shallow groundwater under dairy operations, Environ. Sci. Technol., 41, 759-765, 2007.

Smith, R. L., Garabedian, S. P., and Brooks, M. H.: Comparison of denitrification activity measurements in groundwater using cores and natural-gradient tracer tests, Environ. Sci. Technol., 30, 3448-3456, 1996.

Spalding, R. F. and Exner, M. E.: Occurrence of nitrate in groundwater - A review, J. Environ. Qual., 22, 392-402, 1993.

Spalding, R. F. and Parrott, J. D.: Shallow groundwater denitrification, Sci. Total Environ., 141, 17-25, 1994.

Tesoriero, A. J., Liebscher, H., and Cox, S. E.: Mechanism and rate of denitrification in an agricultural watershed: Electron and mass balance along groundwater flow paths, Water Resour. Res., 36, 1545-1559, 2000.

Turkeltaub, T., Kurtzman, D., and Dahan, O.: Real-time monitoring of nitrate transport in the deep vadose zone under a crop field - Implications for groundwater protection, Hydrol. Earth Syst. Sci., 20, 3099-3108, https://doi.org/10.5194/hess-20-3099-2016, 2016.

Vavilin, V. A. and Rytov, S. V.: Nitrate denitrification with nitrite or nitrous oxide as intermediate products: Stoichiometry, kinetics and dynamics of stable isotope signatures, Chemosphere, 134, 417-426, 2015.

Vitòria, L., Soler, A., Canals, À., and Otero, N.: Environmental isotopes $(\mathrm{N}, \mathrm{S}, \mathrm{C}, \mathrm{O}, \mathrm{D})$ to determine natural attenuation processes in nitrate contaminated waters: Example of Osona (NE Spain), Appl. Geochem., 23, 3597-3611, 2008.

Vogel, J. C., Talma, A. S., and Heaton, T. H. E.: Gaseous nitrogen as evidence for denitrification in groundwater, J. Hydrol., 50, 191200, 1981.

Wassenaar, L. I.: Evaluation of the origin and fate of nitrate in the Abbotsford Aquifer using the isotopes of ${ }^{15} \mathrm{~N}$ and ${ }^{18} \mathrm{O}$ in $\mathrm{NO}_{3}^{-}$, Appl. Geochem., 10, 391-405, 1995.

Wassenaar, L. I., Hendry, M. J., and Harrington, N.: Decadal geochemical and isotopic trends for nitrate in a transboundary aquifer and implications for agricultural beneficial management practices, Environ. Sci. Technol., 40, 4626-4632, 2006.

Weil, R. R., Weismiller, R. A., and Turner, R. S.: Nitrate contamination of groundwater under irrigated coastal plain soils, J. Environ. Qual., 19, 441-448, https://doi.org/10.2134/jeq1990.00472425001900030015x, 1990. 
$\mathrm{Xu}$, S., Kang, P., and Sun, Y.: A stable isotope approach and its application for identifying nitrate source and transformation process in water, Environ. Sci. Pollut. Res., 23, 1133-1148, 2015.

Xue, D., Botte, J., De Baets, B., Accoe, F., Nestler, A., Taylor, P., Van Cleemput, O., Berglund, M., and Boeckx, P.: Present limitations and future prospects of stable isotope methods for nitrate source identification in surface-and groundwater, Water Res., 43, 1159-1170, 2009.
Yang, C.-Y., Wu, D.-C., and Chang, C.-C.: Nitrate in drinking water and risk of death from colon cancer in Taiwan, Environ. Int., 33, 649-653, https://doi.org/10.1016/j.envint.2007.01.009, 2007.

Zirkle, K. W., Nolan, B. T., Jones, R. R., Weyer, P. J., Ward, M. H., and Wheeler, D. C.: Assessing the relationship between groundwater nitrate and animal feeding operations in Iowa (USA), Sci Total Environ., 566-567, 1062-1068, 2016. 